\title{
Revised Korean Thyroid Association Management Guidelines for Patients with Thyroid Nodules and Thyroid Cancer
}

\author{
Ka Hee Yi ${ }^{1}$, Young Joo Park ${ }^{2}$, Sung-Soo Koong ${ }^{3}$, Jung-Han Kim ${ }^{4}$, Dong Gyu Na ${ }^{5}$, \\ Jin-Sook Ryu ${ }^{6}$, So Yeon Park ${ }^{7}$, In Ae Park ${ }^{7}$, Chung-Hwan Baek ${ }^{8}$, \\ Young Kee Shong, ${ }^{9}$ Young Don Lee ${ }^{10}$, Jaetae Lee ${ }^{11}$, Jeong Hyun Lee ${ }^{12}$, \\ Jae Hoon Chung ${ }^{13}$, Chan Kwon Jung ${ }^{14}$, Seung-Ho Choi ${ }^{15}$ and Bo Youn Cho ${ }^{2}$ \\ ${ }^{I}$ Department of Internal Medicine, Korea Cancer Center Hospital, Korea Institute of Radiological \& Medical Sciences, Seoul; and \\ ${ }^{2}$ Department of Internal Medicine, ${ }^{7}$ Pathology, Seoul National University College of Medicine, Seoul; and \\ ${ }^{3}$ Department of Internal Medicine, College of Medicine, Chungbuk National University, Cheongju; and ${ }^{13}$ Departments of Medicine, \\ ${ }^{4}$ Surgery, ${ }^{8}$ Otorhinolaryngology-Head and Neck Surgery, Sungkyunkwan University School of Medicine, Seoul; and \\ ${ }^{5}$ Human Medical Imaging and Intervention Center, Seoul; and ${ }^{9}$ Departments of Endocrinology and Metabolosm, ${ }^{12}$ Radiology, \\ ${ }^{15}$ Otolaryngology, ${ }^{6}$ Nuclear Medicine, University of Ulsan College of Medicine, Seoul; and ${ }^{10}$ Department of Surgury, School of Medicine, \\ Gachon University, Incheon; and ${ }^{11}$ Departments of Nuclear Medicine, Kyungpook National University School of Medicine, Daegu; and \\ ${ }^{14}$ Department of Hospital Pathology, College of Medicine, The Catholic University of Korea, Seoul, Korea
}

\section{대한갑상선학회 갑상선결절 및 암 진료 권고안 개정안}

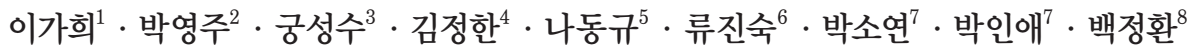
송영기 $^{9} \cdot$ 이영돈 $^{10} \cdot$ 이재태 ${ }^{11} \cdot$ 이정현 $^{12} \cdot$ 정재훈 $^{13} \cdot$ 정찬권 $^{14} \cdot$ 최승호 $^{15} \cdot$ 조보연 ${ }^{2}$

한국원자력의학원 내과학교실, ${ }^{1}$ 서울대학교 의과대학 내과학교실, ${ }^{2}$ 병리과학교실, ${ }^{7}$ 충북대학교 의학전문대학원 내과학교실, ${ }^{3}$ 성균관대학교 의과대학 내과학교실, ${ }^{13}$ 외과학교실, ${ }^{4}$ 이비인후과학교실, ${ }^{8}$ 휴먼영상의학센터, ${ }^{5}$ 울산대학교 의과대학 내분비대사내과학교실, ${ }^{9}$ 영상의학과학교실, ${ }^{2}$ 이비인후과학교실, ${ }^{15}$ 핵의학과학교실, ${ }^{6}$ 가천의과대학 외과학교실, ${ }^{10}$ 경북대학교 의과대학 핵의학과학교실, ${ }^{11}$ 가톨릭대학교 의과대학 병리과학교실 ${ }^{14}$

\section{서 론}

갑상선결절은 매우 흔하며, 그 임상적 중요성은 결절의 일 부(5 10\%)가 갑상선암이라는 사실에 근거한다. 최근 10여 년간 갑상선결절 및 갑상선 분화암의 진단과 치료 분야에서 많은 발전이 있었으며, 갑상선결절 또는 갑상선암의 치료 권 고 안들이 여러 차례 발표된 바 있었다. 그러나 발표된 치료 권고안들 간에도 상충되는 내용이 있고, 아직 임상적으로나 보건의료학적 관점에서 논란이 되는 사항들이 많은 실정이 다. 대한내분비학회 갑상선분과회에서는 갑상선결절 및 갑 상선암 환자의 진료에 종사하는 여러 분야의 의사들에게 도 움을 주고자 2007년 “갑 상선결절 및 암 진료권고안”을 제 정하였다. ${ }^{1)}$ 이 진료 권고안은 국내 주요 의료기관들에서 갑 상선질환 환자를 진료하고 있는 대한내분비학회 회원인 내
과 전문의, 갑상선 수술을 담당하고 있는 대한내분비외과학 회 회원인 외과 전문의, 대한핵의학회가 추천한 핵의학과 전문의 등으로 구성된 실무진으로 구성 된 "갑상선 결절 및 암 진료 지침 제정위원회”에서 2006년에 발표된 미국 갑상 선학회의 권고안과, ${ }^{2}$ 일부 $\mathrm{NCCN}$ 권고안(National Comprehensive Cancer Network: Clinical practice guidelines in on-cology-Thyroid carcinoma, version 1, 2005 http://www. nccn. Org/professionals/physician_gls/PDF/ thyroid. pdf)을 기초로 하여 초안을 작성하고, 작성된 초안 을 2 회의 공청회와 대한내분비학회, 대한내분비외과학회, 대 한핵의학회, 대한신경두경부 영상의학회 갑상선 연구회, 대한 병리학회 내분비 병리연구회 및 대한세포 병리 학회 의견수 렴 과정을 거쳐 제정되었다. ${ }^{1}$

그런데 이 권고안들은 2004 년까지 발표된 연구 결과에 
근거한 것으로, 세계적으로 갑상선결절 및 암의 빈도가 증 가하면서, 이후 많은 수의 갑상선암에 대한임상 연구논문이 발표됨에 따라 이를 반영하여 기존의 권고안을 개정할 필요 성이 대두되었다. 미국갑상선학회에서는 2009년 갑상선결 절 및 암 진료권고안의 개정안을 발표하였으며, ${ }^{3)}$ 2010년에 는 NCCN(Clinical practice guidelines in oncologyThyroid carcinoma, v.1.2010, http://www.nccn.org/professionals/physician_gls/PDF/thyroid. pdf)과 AACE/ AME/ETA(American Association of Clinical Endocrinologists/Associazione Medici Endocrinologi/European Thyroid Association)에서 새로운 진료권고안을 제정 하였다. ${ }^{4}$

우리나라에서도 최근 5년 사이에 특히 갑상선미세암의 빈 도가 급속도로 증가하고 있어, 새로이 보고되는 임상적인 근거에 따른 진료 권고안의 개정 필요성이 대두되고 있다. 우리나라의 갑상선암은 다른 나라에 비해 갑상선유두암의 빈도가 높고, 갑상선 유두암에서 나타나는 BRAFV600E 변이 빈도 또한 매우 높게 나타나는 등의 차이를 보이고 있 으므로, 다른 나라에서 보고된 결과를 그대로 적용하기에 는 많은 제한점이 있다.

대한갑상선학회에서는 우리 실정에 맞는 권고안의 개정을 위하여, 2009년도 미국갑상선학회, 2010년도 NCCN과 $\mathrm{AACE} / \mathrm{AME} / \mathrm{ETA}$ 권고안을 참고로 하여, 대한갑상선학회 를 구성하고 있는 각 학회에서 추천한 내과, 병리과, 영상의 학과, 외과, 이비인후과, 핵의학과 전문의로 구성된 "갑상선 결절 및 암 진료권고안 개정 위원회”를 구성하여 개정안의 초안을 작성하고, 작성된 초안을 2010 대한갑상선학회 추계 학술대회에서 공청회를 가진 후, 개정안 수정안을 작성, 대 한갑상선학회 홈페이지에서 대한갑상선학회 회원의 의견 수 렴과정을 거쳐 확정하였다.

본 진료 권고안 개정안은 2007년에 제정된 권고안과 동일 하게 다음 네 부분으로 구성되어 있는데, 1) 갑상선결절의 진 단 및 치료, 2) 갑상선 분화암의 초기치료, 3) 갑상선분화암 의 장기 치료 및 추적, 4) 기타 갑상선 암이며, 각 부문에서 중 요한 내용들은 권고 사항으로 기술하였으며 각 권고 사항에 대한 권고수준은 Table 1 과 같다.
본 개정안에서 주요 변경된 내용은 1) 갑상선결절에서 위 험인자에 따른 초음파 유도하 세침흡인술의 크기에 대한 기 준, 2) 갑상선 세침흡인세포검사(fine needle aspiration cytology, 이하 FNAC) 진단양식에 대한 Bethesda system ${ }^{5)}$ 적용, 3) 갑상선암의 수술 범위 및 림프절 절제 범위에 대한 것이다. 이 외의 부분은 2007 년에 발표된 내용에서 크게 변 경되지 않았다.

\section{갑상선결절}

갑상선결절은 촉진 혹은 초음파검사로 주변의 정상 갑상 선조직과 뚜렷하게 구별되는 병변이다. 그러나 촉진되는 결 절성 병변이 반드시 방사선학적 이상소견과 일치하지 않을 수 있으며, ${ }^{6)}$ 이러한 병변은 갑상선 결절의 정의에 맞지 않는 다. 촉진되지 않지만 초음파 혹은 다른 방사선학적 검사에 서 발견되는 결절을 “우연히 발견된 결절” 혹은 “우연종”이 라 한다. 촉진되지 않는 결절도 같은 크기의 촉진되는 결절 과 동등한 악성의 위험이 있다. ${ }^{7)}$ 일반적으로 크기가 $1 \mathrm{~cm}$ 이상 인 결절이 임상적으로 의미 있는 암의 위험이 있으므로 검사를 시행한다. 그러나 다음에 기술된 고위험인자를 동반 하지 않으면서, 초음파검사 소견상 완전한 낭종(purely cystic) 혹은 spongiform 소견을 보일 때에는 거의 대부분 양 성이므로 크기가 $2 \mathrm{~cm}$ 이상인 경우에 검사를 고려한다. ${ }^{8-10)}$ 반면, 두경부에 방사선조사의 과거력이 있는 경우, 소아기에 서 청소년기 사이에 전신 방사선조사의 과거력이 있는 경우, 갑상선암의 가족력이 있는 경우, 갑상선암으로 엽절제술을 받은 경우, F-18 FDG-PET 양성인 경우, MEN2/FMTC와 연관된 RET 유전자 변이가 발견 된 경우, 혈청 칼시토닌이 $100 \mathrm{pg} / \mathrm{mL}$ 이상인 경우 등의 고위험군과 초음파검사상 악성 을 시사하는 경우에는 $1 \mathrm{~cm}$ 미만의 결절에서도 검사가 필요 하다. 초음파 검사상 악성을 시사하는 소견은: 1) 앞뒤가 긴 모 양(taller than wide), 2) 침상(spiculated) 혹은 불규칙한 경계, 3) 고형 성분의 현저한 저에코, 4) 미세 및 거대 석회 화, 5) 경부림프절 종대의 동반 등이다. ${ }^{11-15)}$

$1 \mathrm{~cm}$ 미만의 결절에서 어느 정도의 크기까지 $\mathrm{FNAC}$ 를 시 행하여야 하는가에 대해서는 아직까지 확실한 임상 연구 결

Table 1. Strength of recommendations based on availabe evidence

\begin{tabular}{|c|c|}
\hline 권고수준 & 정 \\
\hline 1 & 강력히 권고함: 권고한 행위를 하였을 때 중요한 건강상의 이득 또는 손실이 있다는 충분하고도 객관적인 근거가 있는 경우 \\
\hline 2 & $\begin{array}{l}\text { 권고함: 권고한 행위를 하였을 때 중요한 건강상의 이득 또는 손실이 있다는 근거가 있지만, 근거가 확실하지 않아 일상적으로 행하 } \\
\text { 라고 권고하기 어렵거나 근거가 간접적인 경우 }\end{array}$ \\
\hline 3 & 권고함: 전문가의 의견(expert opinion)에 따라 권고하는 사항 \\
\hline 4 & $\begin{array}{l}\text { 권고 보류: 권고한 행위를 하였을 때 중요한 건강상의 이득 또는 손실이 있다는 근거가 없거나 이견이 많아서, 해당 행위를 하는 것 } \\
\text { 에 대해 찬성도 반대도 하지 않음 }\end{array}$ \\
\hline
\end{tabular}


과가 없어 이견이 많다. $\mathrm{NCCN}(2010)$ 과 Latin American Thyroid Sociey에서는, ${ }^{16)}$ 초음파검사 상 악성을 시사하는 소 견이 있는 경우에, 그리고 $\mathrm{AACE} / \mathrm{AME} / \mathrm{ETA}$ 에서는 두 가지 이상의 악성을 시사 하는 초음파 소견을 보이는 경우에 특 별한 크기의 하한선 제시 없이 $\mathrm{FNAC}$ 를 시행하도록 권고하 고 있다. ${ }^{4)}$ 반면, 미국갑상선 학회에서는 고위험군에서 초음 파검사상 악성을 시사하는 소견이 보이더라도 결절의 크기 가 $0.5 \mathrm{~cm}$ 보다 큰 경우 에만 $\mathrm{FNAC}$ 를 시행하고, 전이가 의심되는 경부림프절종대가 동반된 경우에만 크기에 제한 없이 FNAC를 시행할 것을 권고하고 있다. ${ }^{3)}$ 그러므로 $1 \mathrm{~cm}$ 미만의 갑상선결절에서 $\mathrm{FNAC}$ 의 시행 여부는 각 개인의 위 험인자와 초음파검사 소견을 고려하여 결정되어야 한다. 본 권고안에서는, 대부분의 $0.5 \mathrm{~cm}$ 이하의 갑상선암은 예후가 양호하고, $0.5 \mathrm{~cm}$ 이하의 결절에서 $\mathrm{FNAC}$ 를 시행할 때에 부 적절한 검체의 빈도가 높은 점을 고려하여, 고위험군이거 나 초음파검사상 악성을 시사하는 소견을 보이는 경우 0.5 $\mathrm{cm}$ 보다 큰 경우에만 $\mathrm{FNAC}$ 를 시행하는 것을 우선적으로 고려한다. 다만, 악성이 의심되는 경부림프절 종대가 동반된 경우에는 크기에 관계없이 $\mathrm{FNAC}$ 를 시행하여야 한다. 그러 나 이러한 크기의 기준에 대해 우리나라에서 수행된 연구결 과는 아직 없는 상태로, 향후 확실한 권고안을 위해서는 이 에 대한 연구가 요구된다.
임상적 혹은 우연히 발견된 갑상선결절의 적절한 검사법

갑상선결절이 발견되면 갑상선과 주위 경부 림프절에 관 심을 둔 면밀한 병력청취 및 신체검사를 시행한다(Fig. 1: 하나 혹은 그 이상의 갑상선 결절을 가진 환자의 평가 알고 리듬), 두경부 방사선조사, 골수 이식을 위한 전신 방사선 조 사, ${ }^{17)}$ 갑상선암의 가족력, 14 세 이전 체르노빌의 방사선 낙진 노출, ${ }^{18)}$ 급격한 크기 증가 및 쉰 목소리는 암을 시사하는 병 력들이다. 성대 마비, 동측 경부림프절종대, 결절이 주위 조 직에 고정되어 있음은 암을 시사하는 신체검사 소견들이다.

\section{갑상선결절의 진단에 필요한 혈액검사 및 영상진단법}

\section{$\mathrm{TSH}$ 와 영상진단법}

갑상선결절이 발견되면 혈청 $\mathrm{TSH}$ 를 포함한 갑상선기능검 사를 시행한다. TSH가 정상보다 낮으면 결절이 열결절, 온 결절 혹은 냉결절인지를 알기 위해 갑상선스캔을 시행한다. 열결절은 악성의 가능성이 거의 없기 때문에 FNAC 검사를 생략할 수 있다. 만일 갑상선중독증이 있는 경우라면 추가 적인 검사가 필요하다.

- 갑상선결절의 초기 검사에 $\mathrm{TSH}$ 를 포함한 갑상선기능검사 를 시행한다. TSH가 정상보다 낮으면 갑상선스캔을 시행한다. 권고수준 1

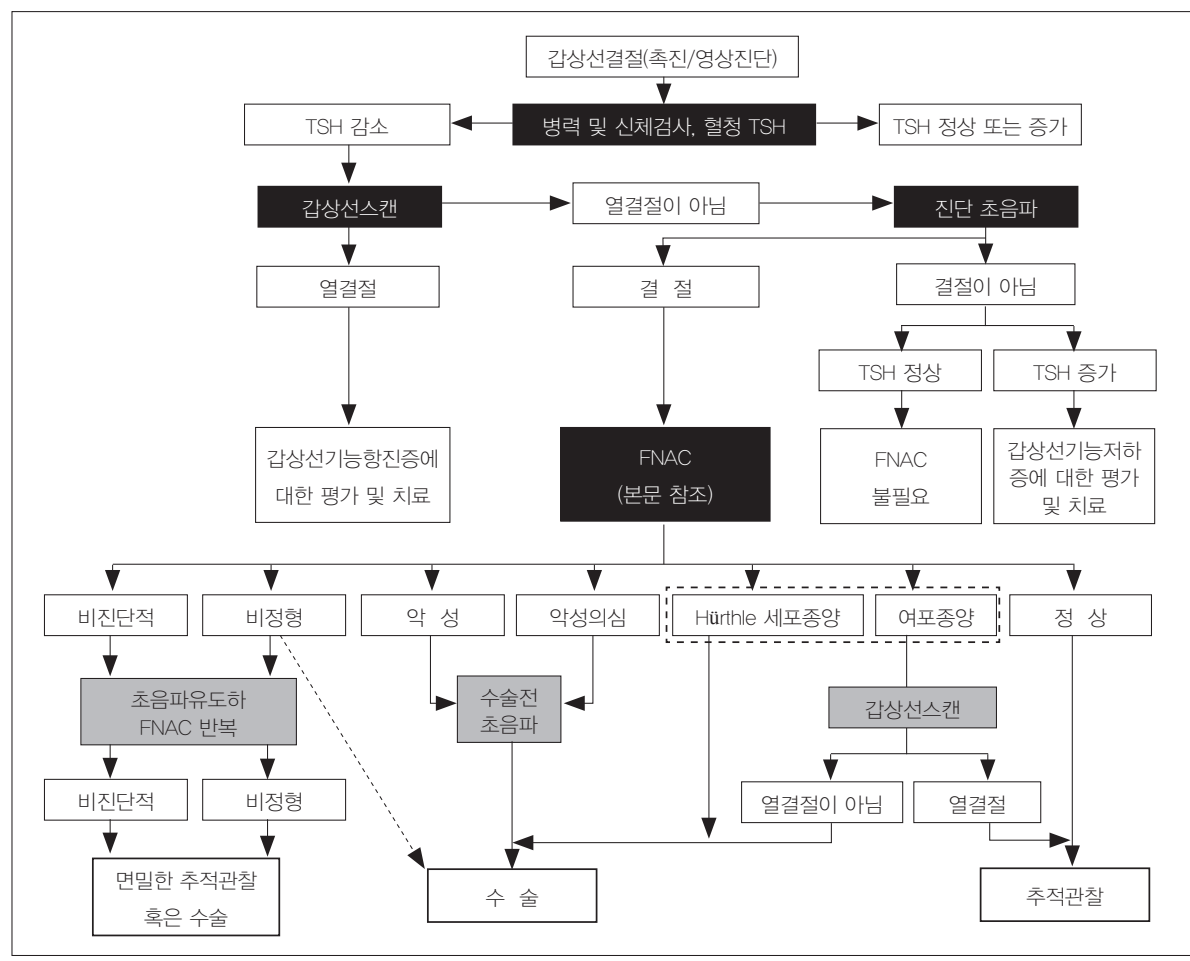

Fig. 1. Algorithm for the evaluation patients with one or more thyroid nodules. 
혈청 TSH 농도가 낮지 않다면 갑상선스캔을 생략하고 갑상선초음파를 시행할 수 있다. 갑상선초음파를 통해 촉진 되는 이상소견이 정말 결절인지, 결절이 얼마나 큰지, 악성 또 는 양성을 시사하는 소견을 보이는지, 결절이 $50 \%$ 이상의 낭성 변화를 가졌는지, 그리고 결절의 위치가 갑상선의 후 방에 존재하는지를 확인할 수 있기 때문이다. 특히 뒤의 두 가지 특성이 있는 결절의 경우 촉진으로 시행한 $\mathrm{FNAC}$ 의 정확성이 떨어진다. ${ }^{19)}$ 갑상선 초음파를 시행하면 촉진되는 주결절 이외에 크기 및 외견상 $\mathrm{FNAC}$ 를 필요로 하는 결절 을 추가로 발견할 수도 있다. ${ }^{6,20,21)}$ 혈청 TSH 농도가 증가되 어 있는 경우에도 $\mathrm{FNAC}$ 를 시행해야 하는 데 이는 하시모 토 갑상선염에 이환된 갑상선에서 발생하는 갑상선암의 빈도 가 정상 갑상선과 비교하여 같거나 높기 때문이다. ${ }^{22,23)}$

- 갑상선결절이 존재하거나 의심되는 모든 환자에서 갑상선 초음파 시행을 고려한다. 권고수준 1

\section{기타 혈액검사법}

혈청 갑상선글로불린(thyroglobulin, $\mathrm{Tg}$ ) 농도 측정: 대 부분의 갑상선질환에서 혈청 $\mathrm{Tg}$ 농도가 증가할 수 있으므 로 갑상선암의 진단에는 민감도와 특이도가 낮다. ${ }^{24}$

- 갑상선결절의 초기 검사에 일상적인 혈청 $\mathrm{Tg}$ 농도 측정은 필요하지 않다. 권고수준 1

혈청 칼시토닌 농도 측정: 칼시토닌의 이용에 관해서는 몇 개의 전향적인 비무작위 연구들이 있으며, ${ }^{25-27)}$ 선별검사 로 일상적 칼시토닌 농도를 측정할 경우 조기에 $\mathrm{C}$ 세포 증식 증과 갑상선수질암을 진단할 수 있어 전반적인 생존율을 개 선시킬 수 있음을 보여주었다. 그러나 민감도, 특이도, 검사 수행법과 비용효율성 등 해결해야 할 문제가 남아 있다. 기 저 혈청 칼시토닌 농도가 $100 \mathrm{pg} / \mathrm{mL}$ 이상이라면 갑상선수 질암의 가능성은 높다. ${ }^{28)}$

- 갑상선 결절의 초기 검사로 혈청 칼시토닌의 측정을 고려 할 수 있다. 권고수준 3

\section{갑상선결절의 진단에 있어 미세침흡인세포검사의 역할}

$\mathrm{FNAC}$ 는 갑상선결절을 진단하는데 가장 정확하고, 가장 비용-효율적인 방법이다. 전통적으로 FNAC의 결과는 비진 단적, 악성, 미결정, 양성 세포소견과 같은 네 가지 범주로 분 류되었다. 2009년 "National Cancer Institute Thyroid Fine-Needle Aspiration State of the Science Confer-
Table 2. The Bethesda system for reporting thyroid cytopathology

1 Nondiagnostic or unsatisfactory

Cyst Fluid Only

Vertually acellular specimen, No follicular cells present Other (obscuring blood, clotting artifact, poor fixation, poor cell preservation etc)

2 Benign

Consistent with a benign follicular nodule (includes adenomatoid nodules, colloid nodule, etc.)

Consistent with lymphocytic (Hashimoto) thyroiditis in the proper clinical context

Consistent with granulomatous (subacute) thyroiditis Other

3 Atypia of undetermined significance or follicular lesion of undetermined significance

4 Follicular neoplasm or suspicious for a follicular neoplasm Specify if Hürthle cell (oncocytic) type

5 Suspicious for malignancy

Suspicious for papillary carcinoma Suspicious for medullary carcinoma Suspicious for metastatic carcinoma Suspicious for lymphoma

Other

6 Malignant

Papillary thyroid carcinoma

Poorly differentiated carcinoma

Medullary thyroid carcinoma

Undifferentiated (anaplastic) carcinoma

Squamous cell carcinoma

Carcinoma with mixed features (specify)

Metastatic carcinoma

Non-Hodgkin lymphoma Other

ence"에서 발표한 Bethesda system은 두 개의 범주를 추 가하여 1) 비진단적, 2) 양성, 3) 비정형(atypia of undetermined significance or follicular lesion of undetermined significance), 4) 여포종양 혹은 여포종양 의심(Hürthle 세포 유형이면 구별하여 진단), 5) 악성 의심, 6) 악성으로 분 류한다(Table 2). ${ }^{5}$ 비진단적 세포소견은 정립 된 적절성의 기준을 ${ }^{29)}$ 만족하지 못하는 경우로 전이가 의심되는 경부림 프절(cervical lymph-adenopathy)을 동반하지 않았다면, 초음파 유도하 FNAC를 다시 시행해야 한다. ${ }^{30)}$ 어떤 결절들 (특히 낭성결절)은 반복적인 검사에도 불구하고 지속적으로 비진단적 세포소견을 보이다가 수술 시 비로소 악성 결절로 확인되는 경우도 있다. ${ }^{31,32)}$

갑상선암의 병리학적 분류에 대한 표기는 "유두암종”, “소 포암종”, “수질암종”이 옳으나, 갑상선암에는 육종(sarcoma) 이 매우 드물고, 대부분이 암종(carcinoma)이므로, 본 권고 안에서는 임상적으로 사용해오던 "유두암" "여포암", “수질 암” 등으로 표기하였다. 
- 갑상선결절의 평가에 있어 $\mathrm{FNAC}$ 는 가장 좋은 검사법이다. 권고수준 1

비진단적 결과(Nondiagnostic/unsatisfactory)

검체의 적절성(보존이 잘된 10 개 이상의 여포 세포로 이루 어진 세포 군집이 6 개 이상 보여야 함) 기준에 미흡한 경우 이다. 예외적으로, 아무리 세포가 적게 나오더라도 뚜렷한 비 정형 세포가 보일 때에는 비진단적으로 진단하지 않으며, 심 한 염증을 동반한 고형 결절이거나 콜로이드 결절일 경우에 는 세포가 적게 나오더라도 양성으로 진단을 할 수 있다. ${ }^{5}$

- 반복적인 FNAC에도 비진단적인 낭성 결절은 주의 깊은 추적 관찰 혹은 수술적 절제를 필요로 한다. 특히 세포학적으로 비진 단적인 결절이 고형결절 이라면 수술을 고려한다.

\section{권고수준 2}

\section{양 성}

- 세포학적으로 양성인 경우 즉각적인 추가 검사 및 일상적 인 치료는 필요하지 않다. 권고수준 1

비정형(atypia of undetermined significance or follicular lesion of undetermined significance)

종종 “여포병변(follicular lesion)”, “비정형(atypical)”, “여포종양(follicular neoplasm)”, "미결정종양(indeterminate for neoplasia)", "악성 의심스러운(suspicious for malignancy)"으로 혼용되어 보고 되는 결과를 미결정이라는 한 가지 범주로 간주되기도 하였으나, 이러한 결과 내에서도 악 성 위험도가 다르기 때문에 Bethesda system은 용어를 구 분하여 사용한다. "비정형(atypia of undetermined significance)"은 여포종양의심, 악성의심, 혹은 악성으로 진단하 기에는 불충분한 세포의 구조적 혹은 핵 모양의 이형성을 보일 때 진단된다. 이 경우 악성 위험도는 5 15\%이다. ${ }^{5)}$ 비정 형 세포 소견으로 나온 결절에 대해서 $\mathrm{FNAC}$ 를 다시 시행하 는 경우 대부분 진단적인 결과를 얻을 수 있으며, 단지 20 25\%에서만 다시 “비정형”으로 진단되므로, ${ }^{33,34)}$ 진단의 정확성을 높이기 위하여 $\mathrm{FNAC}$ 를 반복하는 것을 우선적으 로 고려할 수 있다. ${ }^{5)}$ 반복한 FNAC 세포 소견에서도 비진단 적인 결과를 얻은 경우에는 임상적 위험 인자를 고려하여 면 밀한 추적 관찰을 하거나 수술을 고려한다.
여포종양 혹은 여포종양 의심(follicular neoplasm/ suspicious for a follicular neoplasm)

Hürthle 세포 종양은 세포 형태학적으로 모양이 여포종양 과 다르며 유전학적 으로도 다르기 때문에 Bethesda system은 구분하여 진단한다(진단 예, follicular neoplasm, Hürthle cell type/suspicious for a follicular neoplasm, Hürthle cell type). 이 경우 악성의 위험도는 약 15 30\% 이다. ${ }^{5)}$

성별, 결절 크기, 나이와 같은 임상소견 ${ }^{35)}$ 및 세포학적 특 징하이 비정형 또는 여포종양 혹은 여포종양 의심 세포소견 결과에서 진단의 정확성을 개선시킬 수는 있으나, 전반적으 로 악성을 예측하는데 그 가치는 낮은 편이다. 비정형 또는 여포 종양 혹은 여포종양 의심 세포소견 결절에서 진단의 정확성을 높이기 위해 많은 분자 표지자들이 연구되었으며 임상적 결정에 도움을 주고 있다. ${ }^{37-39)}$

- 세포학적 판독이 여포종양인 경우, 특히 혈정 TSH 치가 정 상범위 내에 있더라도 낮은 편이라면 갑상선스캔의 시행을 고 려할 수 있다. 스캔에서 결절과 일치하는 자율기능성 결절이 관찰되지 않는다면 엽절제술 혹은 갑상선전절제술 을 고려한 다. 권고수준 3

- 만일 세포학적 판독이 “Hürthle세포종양”인 경우 갑상선스 캔은 필요하지 않으며, 엽절제술 혹은 갑상선전절제술을 시행 한다. ${ }^{40)}$ 권고수준 1

- "비정형”이나 "여포종양 혹은 여포종양 의심"의 세포 소 견인 경우, 결절에 대한 진단의 정확성을 높이기 위하여 특 정 분자 표지자(BRAF, RAS, RET/PTC, Pax8-PPARy, galectin-3, cytokeratin-19 등) 검사를 고려할 수 있다. 권 고수준 3

악성 의심(Suspicious for malignancy)

악성이 강력히 의심되지만 악성으로 확진 하기에는 세포학 적 소견이 부족할 때 진단하며, 이 경우 악성 위험도는 60 $75 \%$ 정도이다. ${ }^{5)}$ 여포 종양이나 Hürthle 세포 종양을 의심 하는 경우는 "악성의심" 진단에 포함되지 않는다.

- 만일 세포학적 판독이 "갑상선 유두암 의심(악성 의심)"인 경 우 갑상선 스캔 은 필요하지 않으며, 엽절제술 혹은 갑상선전절 제술을 시행한다. ${ }^{40)}$ 권고수준 1 
악성(Malignancy)

- 세포학적 결과가 악성인 경우 수술을 권고한다. ${ }^{41}$ 권고수준 1

\section{다결절성 갑상선종}

다결절성 갑상선종 환자의 악성 위험도는 단일 결절 환자와 동일하다. ${ }^{12)}$ 결절들의 특성을 확인하기 위해 갑상선초음파 를 시행한다. 만약 주결절 혹은 가장 큰 결절에서만 $\mathrm{FNAC}$ 를

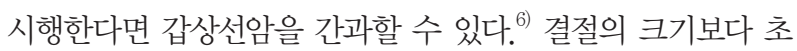
음파 소견으로 악성의 가능성이 높은 결절을 찾는 것이 진단 효율이 더 높다. ${ }^{12,42)}$

- 2 개 이상의 결절이 관찰되는 경우 초음파 소견상 악성의 가능성이 높은 결절 에서 우선적으로 FNAC를 시행할 수 있 다. 권고수준 2

- 초음파 소견상 악성이 의심되는 결절이 없고 초음파 소견 이 유사한 융합성 결절들이 다수 관찰된다면 악성의 가능성은 낮으며 가장 큰 결절에서만 $\mathrm{FNAC}$ 를 시행해도 무방하다. 권 고수준 3

- 혈청 TSH 농도가 낮은 경우 자율기능성을 가진 결절이 존 재할 수 있으므로 갑상선스캔을 시행해야 하며, 각 결절들의 기능성을 평가하기 위해 초음파와 직접 비교해야 한다. 초음 파에서 의심스러운 소견이 있는 결절들 중에서 온결절 혹은 냉결절에 대해서 우선적으로 FNAC를 고려한다. 권고수준 2

\section{갑상선결절 환자의 장기 추적관찰에 좋은 방법}

$\mathrm{FNAC}$ 는 약 $5 \%$ 정도의 무시할 수 없는 위음성률을 보이 므로 추적관찰이 필요하다. ${ }^{4344)}$ 양성 결절은 크기가 감소할 수 있지만 서서히 크는 경우가 더 흔하다. ${ }^{45)}$ 결절의 크기 증 가 그 자체가 악성을 시사하지는 않지만, 반복적인 FNAC 의 적응증이다. 초기 양성 결과를 보였던 갑상선결절의 추 적 관찰에 대한 최근 일련의 연구결과들은 초음파유도 $\mathrm{FNAC}(0.6 \%)$ 보다, ${ }^{46)}$ 촉진으로 시행한 $\mathrm{FNAC}$ 의 위음성률 (1 3\%)이 더 높았다. ${ }^{46-48)} \mathrm{FNAC}$ 결과 양성으로 판독된 306 명의 환자를 주기적으로 반복하여 $\mathrm{FNAC}$ 를 시행한 연구에 서는 매우 드물게 3 명의 환자에서 결국 악성으로 진단되었 다고 보고하였다. ${ }^{48)}$ 초음파에 비해 촉진으로 결절의 크기 변화를 판단하는 것이 부정확하기 때문에, ${ }^{21)}$ 임상적으로 의 미있는 크기 변화를 판단하기 위해서는 정기적인 갑상선초 음파를 시행해야 한다. 하지만 결절의 성장을 정의하는 기준 이나 $\mathrm{FNAC}$ 재검이 필요한 결절 크기 증가의 역치에 대해 일 치된 의견은 없다. 몇몇 연구자들은 결절 용적의 $15 \%$ 이상
증가를 주장하지만 결절의 평균 직경의 변화를 측정할 것을 권하는 연구자도 있다. ${ }^{45,49)}$ 결절의 직경이 최소 두 측정 장소 이상에서 $2 \mathrm{~mm}$ 이상 증가 되면서 $20 \%$ 증가되는 것을 결절 성장의 정의로 이용하는 것은 타당하다. 반복된 $\mathrm{FNAC}$ 에서 양성인 경우 위음성률은 낮다. ${ }^{50)}$

- 모든 결절들은 첫 FNAC 6 18개월 이후 초음파검사가 필 요하며, 만약 결절 크기에 변화가 없으면 추적관찰의 간격을 증가시킬 수 있다. 권고수준 3

- 촉진 혹은 초음파 소견상 결절 크기가 증가하는 경우 가급 적이면 촉진을 통한 FNAC보다는 초음파유도 FNAC를 다시 시행하는 것이 좋다. 권고수준 2

- 재발하는 낭성 결절은 양성인 경우라도 압박 증상이나 외 관상의 문제가 발생하면, 수술 혹은 에탄올절제술(ethanol ablation)을 고려할 수 있다. 권고수준 2

\section{양성 갑상선결절에서 약물치료의 역할}

많은 무작위 연구와 3 개의 메타분석의 결과에서 얻어진 증거들은 경계범위의 저요오드 섭취지역의 경우 혈청 $\mathrm{TSH}$ 농도를 정상 이하로 억제시키는 갑상선호르몬 치료가 결절 의 크기를 줄일 수 있음을 보여주었다. 하지만 요오드 섭취 가 충분한 인구군에서 얻어진 결과는 설득력이 낮다. ${ }^{51-53)}$

- 모든 양성 갑상선결절에 대한 일상적인 억제치료는 권고하 지 않는다. 권고수준 1

- 결절의 크기가 증가되어 반복 시행한 세포검사에서 양성을 보인 경우에는 증상이나 임상적 염려에 근거하여 지속적인 추 적관찰 혹은 수술적 개입을 고려 할 수 있다. 하지만 이러한 환자군에서 갑상선호르몬 억제치료에 대한 자료는 없다. 권 고수준 4

\section{소아나 임신부의 갑상선결절}

\section{소아의 갑상선결절}

성인에 비해 소아에서는 갑상선결절이 적다. 미국 남서부 의 11 세부터 18 세 사이 5,000 명의 소아를 대상으로 한 연구 에서는 1,000 명당 20 명에서 촉진되는 갑상선결절이 발생하 였고, 매년 1,000 명당 7 명의 발생률을 보고하였다. ${ }^{54)}$ 소아 의 갑상선결절에서 갑상선암의 빈도는 한 연구에 의하면 $15 \sim 20 \%$ 정도로 성인에 비해 높음을 보고하였으나, ${ }^{55-57)}$ 다 른 연구자들은 성인과 비슷하다고 하였다. ${ }^{58,59)} \mathrm{FNAC}$ 는 소 아기 갑상선 결절의 진단에 있어 민감하고 특이적이다. ${ }^{55-58)}$ 
- 소아에서 한 개 혹은 그 이상의 결절에 대한 진단 및 치료 적인 접근은 성인 에서와 같다(임상검사, 혈청 TSH, 초음파, $\mathrm{FNAC)}$. 권고수준 1

\section{임산부에서의 갑상선결절}

임산부에서 발견되는 갑상선결절의 악성 가능성이 비임산 부에 비하여 높은지는 명확하지 않다. ${ }^{60)}$ 갑상선스캔이 금기 라는 것을 제외하면 결절의 검사법은 임신이 아닐 때와 같다.

- 정상 갑상선기능 혹은 갑상선기능저하증을 가진 임산부의 갑상선결절을 대상 으로 FNAC를 시행한다. 임신초기(first trimester) 이후에도 지속적으로 혈청 TSH 농도가 감소된 임산 부에서는 결절의 기능을 평가할 수 있는 갑상선스캔 이 가능 해지는 출산 이후로 FNAC를 미룰 수 있다. 권고수준 1

임산부에서 FNAC 결과가 악성으로 나온 경우 수술이 권 고된다. 그러나 수술을 언제 시행해야 하는지(임신 중 혹은 분만 후)에 대해서는 일치된 의견이 없다. 유산 등의 위험성 을 최소화하기 위해서는 임신 24주 이전에 시행해야 한다. ${ }^{61)}$ 그러나 임신 중 발견된 갑상선암이 같은 연령대의 비임신 여 성의 갑상선암에 비해 더 공격적이라는 증거는 없다. ${ }^{62,63)}$ 갑 상선분화암이 발견된 임산부를 대상으로 한 후향적 연구 결 과에 의하면 임신 중 혹은 분만 후에 수술을 시행한 경우 재발이나 생존율 모두에서 차이가 없었다. ${ }^{63)}$ 또 다른 후향 적 연구 결과는 갑상선암 진단 이후 1 년 이내의 치료지연은 환자의 예후에 악영향이 없음을 시사하였다. ${ }^{64)}$

- 임신 초기에 진단된 갑상선암은 초음파 추적관찰이 필요하 며, 임신 24주까지 의미있는 성장(위의 정의)을 보이는 경우 수술을 시행한다. 그러나 임신 중기까지 결절크기의 변화가 없 거나, 임신 후기에 처음 갑상선암이 진단된 경우라면 분만 후 에 수술을 시행할 수 있다. 진행된 갑상선암은 임신 중기에 수 술을 시행 하는 것이 바람직하다. 권고수준 3

- FNAC 결과가 악성이 의심되는 경우에는 임신기간 동안 혈 청 TSH가 0.1 1 mU/L 사이를 유지하도록 갑상선호르몬제의 투여를 고려할 수 있다. 권고수준 3

\section{갑상선분화암의 초기 치료}

\section{갑상선분화암의 초기치료 목적}

1) 원발종양의 제거와 피막 및 경부 림프절 등에 전이된
병소를 제거함. 완전한 수술적 절제는 치료성과를 결정하는 중요한 관건이 된다. ${ }^{65-67)}$

2) 질병 및 치료와 연관된 이환율의 최소화. ${ }^{68,69)}$

3) 정확한 병기결정. ${ }^{70,71)}$

4) 수술 후 방사성요오드 치료를 용이하게 함. ${ }^{72)}$

5) 재발에 대한 적절한 장기적 관리. ${ }^{73)}$

6) 재발과 전이의 최소화. ${ }^{73-76)}$

\section{진단적 영상검사와 검사실 검사를 통한 수술 전 병기결정}

\section{경부 영상검사}

표준 병리학적 기법을 이용하였을 때, 수술을 시행한 갑상 선분화암(특히 갑상 선유두암) 환자의 20 50\%에서 경부 림프절전이가 발견된다. ${ }^{77-81)} 20 \sim 31 \%$ 의 환자에서 수술 전 초음파로 전이가 의심되는 경부 림프절 병변이 발견되며, 그 런 경우에는 수술 범위가 변경될 수 있다. ${ }^{82,83)}$ 초음파검사가 검사자에 의존하는 특성을 고려하여 $\mathrm{CT}, \mathrm{MRI}, \mathrm{PET}$ 스캔 의 민감도가 알려져 있지 않았음에도 불구하고, 필요에 따라 초음파 외의 다른 영상기법들이 사용될 수 있다. ${ }^{84,85)}$

- 악성 세포소견으로 갑상선절제술을 시행 받을 모든 환자에 게 반대쪽 엽과 경부 림프절 평가를 위한 수술 전 경부 초음 파를 고려한다. 권고수준 2

\section{혈청 $\mathrm{Tg}$ 농도 측정}

수술 전의 혈청 $\mathrm{Tg}$ 농도의 측정이 환자의 치료나 치료결과 에 영향을 준다는 증거는 아직 없다.

- 수술 전의 일상적인 혈청 $\mathrm{Tg}$ 농도 측정은 일반적으로 권고 하지 않는다. 권고수준 2

\section{갑상선분화암에 대한 적절한 수술}

갑상선 수술의 목적은 비진단적이거나 비정형 세포소견을 보이는 경우의 확진, 갑상선암의 제거, 병기결정, 방사성요 오드 치료의 준비 등이다. 갑상선 암의 수술은 갑상선엽절 제술(lobectomy), 갑상선근전절제술(near total thyroidectomy), 반회후두신경이 cricothyroid 근육으로 들어가 는 부위에 약 $1 \mathrm{~g}$ 의 갑상선조직만을 남기고 눈에 보이는 모 든 갑상선을 제거하는 것), 그리고 갑상선전절제술(total thyroidectomy, 육안적으로 보이는 모든 갑상선조직을 제 거하는 것)의 세 가지에 한정되어야 한다. 
비진단적이거나 비정형, 여포종양 혹은 여포종양 의심, 또 는 악성의심의 세포소견을 보이는 경우, 위험인자들을 고려 한 수술방법의 선택

- "비정형" 또는 "여포종양 혹은 여포종양 의심" 세포소견을 보이는 단일결절 이 있고, 보다 제한적인 수술을 원하는 환자에 게는 초기 치료로 갑상선엽 절제술이 추천된다. 권고수준 3

- 세포검사에서 "악성 의심" 세포 소견이거나, "비정형" 또는 "여포종양 혹은 여포종양 의심" 세포소견을 보이는 $4 \mathrm{~cm}$ 이 상의 큰 결절을 가지거나, 세포 소견에서 심한 비정형(marked atypia) 소견을 보이거나, 갑상선암의 가족력이 있거나, 방사선 조사의 과거력이 있는 환자들에서는 암의 위험도가 증가하므 로 갑상선전절제술을 적용할 수 있다. ${ }^{35,86,87)}$ 권고수준 1

- 양쪽 엽에 갑상선결절이 있거나, 혹은 반대편 엽의 재수술 의 가능성을 피하고자 처음부터 양쪽 완전한 제거를 원하는 환자들 역시 갑상선 전절제술을 적용할 수 있다. 권고수준 3

\section{세포검사에서 암이 진단적인 경우의 수술}

최근 발표된 대규모 연구결과 ${ }^{88)}$ 에 의하면 갑상선암의 크 기가 $1 \mathrm{~cm}$ 이상인 경우에는 엽절제술을 시행한 경우, 갑상선 전절제술 혹은 갑상선 근전절제술을 시행하였을 때 보다 재 발률 뿐만 아니라 사망률도 높게 나타나므로, $1 \mathrm{~cm}$ 이상의 갑상선암 환자의 초기 수술은 갑상선전절제술 혹은 갑상선 근전절제술을 시행하는 것이 적극적으로 권고된다. 단일 병 소이고 크기가 $1 \mathrm{~cm}$ 미만으로 작고, 갑상선 내에 국한되어 있고, 주변 경부 림프절전이가 없는 저위험군 갑상선유두암 환자에서도 갑상선전절제술 혹은 갑상선근전절제술이 재발 율을 감소시키는 것으로 보고되고 있으나, ${ }^{89-91)}$ 아직까지 사 망률 감소에 대한 증거가 없으므로, 수술에 따른 합병증의 발생 등을 고려하여 갑상선엽절제술을 고려할 수도 있다. ${ }^{3)}$ 그러나, 반대편 엽에 갑상선결절이 있을 때, 갑상선 주위나 다른 부위로의 전이, 경부에 방사선조사의 과거력이 있는 환자들, 1 세대 내에 갑상선분화암의 가족력이 있는 경우에는 갑상선전절제술 혹은 갑상선근전절제술이 권장된다. ${ }^{88)}$ 환자 가 45 세 이상인 경우 재발이 보다 흔하므로 갑상선전절제 술 혹은 갑상선근전절제술을 고려할 수 있다. ${ }^{65,71,72,92,93)}$

- $1 \mathrm{~cm}$ 이상의 갑상선암 환자들에서는 처음 수술로 갑상선전 절제술이나 갑상선 근전절제술을 시행하여야 한다. 권고수준 1

- 단일병소이고 크기가 $1 \mathrm{~cm}$ 미만으로 작고, 갑상선 내에 국 한되어 있으며, 주변 경부 림프절전이가 없는 저위험군 갑상선 유두암 환자에서는 갑상선엽절제술을 고려할 수 있다. 권고 수준 3

\section{림프절절제술}

갑상선유두암에서는 진단 당시 주변 림프절전이가 있는 경 우가 20 90\%이지만, 많은 경우에서 육안적으로 이상이 없 어 보인다. ${ }^{94)}$ 그 외 다른 조직형에서는 경부림프절 전이는 그보다 적다. ${ }^{77,95)}$ 림프절전이가 명백한 경우 양쪽 중앙 림프 절 절제술이 생존율을 향상시키고, 경부 림프절 재발의 위 험도를 낮춘다. ${ }^{78,94)}$ 이러한 중앙 림프절절제술은 합병증을 증가 시킬 수 있으므로 신중하게 선택하여야 한다. ${ }^{96-99)}$

- 림프절전이가 명백한 경우에는 중앙 림프절절제술을 시행 해야 한다. 권고수준 2

- 림프절 전이가 명백하지 않더라도 갑상선유두암이 의심되 는 환자, 특히 T3 혹은 T4 병변이 의심되는 경우에서는 예방 적 중앙(level VI) 림프절절제술을 고려할 수 있다. 권고수준 3

- 원발암의 크기가 작고(T1 또는 T2), 비침습적이며 임상적으 로 림프절 전이가 없는 갑상선유두암 및 대부분의 여포암 환 자에서는 예방적 림프절절제술 없이 갑상선전절제술 또는 갑 상선근전절제술을 하는 것이 적절할 수 있다. 권고수준 3

측경부(level II-IV)와 후삼각(level V)의 림프절들은 갑 상선암, 특히 갑상선유두암 및 Hürthl 세포암과 연관되어 있 다. ${ }^{77,100)}$ 임상적으로나 수술 전 초음파에서, 혹은 수술 중에 확인되는 이들 부위의 림프절 전이가 있는 환자들에서는 수 술적 림프절절제가 암 재발률을 낮출 수 있고, 사망률에도 영향을 미칠 가능성이 있다. ${ }^{95,101,102)}$ 제한적이기는 하지만 기 능적인 광범위 구역절제가 사망률을 낮출 수 있다는 보고가 있어, 선택적인 절제(berry picking)보다 선호된다. ${ }^{67,103-105)}$

- 조직검사 또는 세포검사로 측경부 림프절 전이가 확인된 환자에서는 치료적 측경부 림프절절제술을 시행해야 한다. 권고수준 2

\section{잔존갑상선절제술(Completion thyroidectomy)}

잔존갑상선절제술은 갑상선엽절제술 후에 암의 진단이 확 실해진 경우에 필요하다. 대부분의 연구에 의하면 갑상선유 두암에서 먼저 절제한 갑상선엽에 다발성 병변이 있는 경우, 단일 병변에 비해 반대쪽 갑상선에 암이 있을 가능성이 더 높다. ${ }^{106-108)} 2$ 단계 갑상선수술(갑상선엽절제술 후에 잔존갑 상선절제술)의 수술 위험도는 갑상선전절제술이나 갑상선근 전절제술과 비슷하다. ${ }^{109,110)}$ 
- 잔존갑상선절제술은 처음 수술 전 갑상선분화암으로 진단 되었다면 갑상선 전절제술이나 갑상선근전절제술이 추천되었 을 모든 환자들에게 고려한다. 크기가 작고, 단일병소이며, 갑 상선 내에 국한되고, 림프절 전이가 없고, 저위험군인 환자들 을 제외한 모든 환자들이 여기에 해당된다. 권고수준 2

- 잔존하는 갑상선조직에 대한 방사성요오드 치료가 잔존갑 상선절제술의 대안으로 여겨져 왔으나, ${ }^{111)}$ 이러한 방법이 비슷 한 결과를 보이는지는 아직 알 수 없다. 결론적으로, 방사성요 오드 치료가 잔존갑상선절제술의 대안으로 추천하지는 않는 다. 권고수준 2

\section{수술 후 병기결정}

\section{수술 후 병기결정의 역할}

1) 갑상선분화암 환자의 예후를 예측하고, 2) 방사성요오 드 치료나 $\mathrm{TSH}$ 억제와 같은 수술 후 치료방침을 결정하고, 3) 수술 후 추적의 빈도와 강도를 결정하고, 4) 의료진 간의 의사소통을 위해 수술 후 병기 결정이 필요하다.

\section{AJCC/UICC TNM 병기}

$\mathrm{pTNM}$ 에 근거한 $\mathrm{AJCC} / \mathrm{UICC}$ 병기분류의 적용이 갑상선 암을 비롯한 모든 암에 권장하고 있다(Table 3 and 4). ${ }^{70,112)}$

Table 3. Definition of TNM status for differentiated thyroid carcinoma

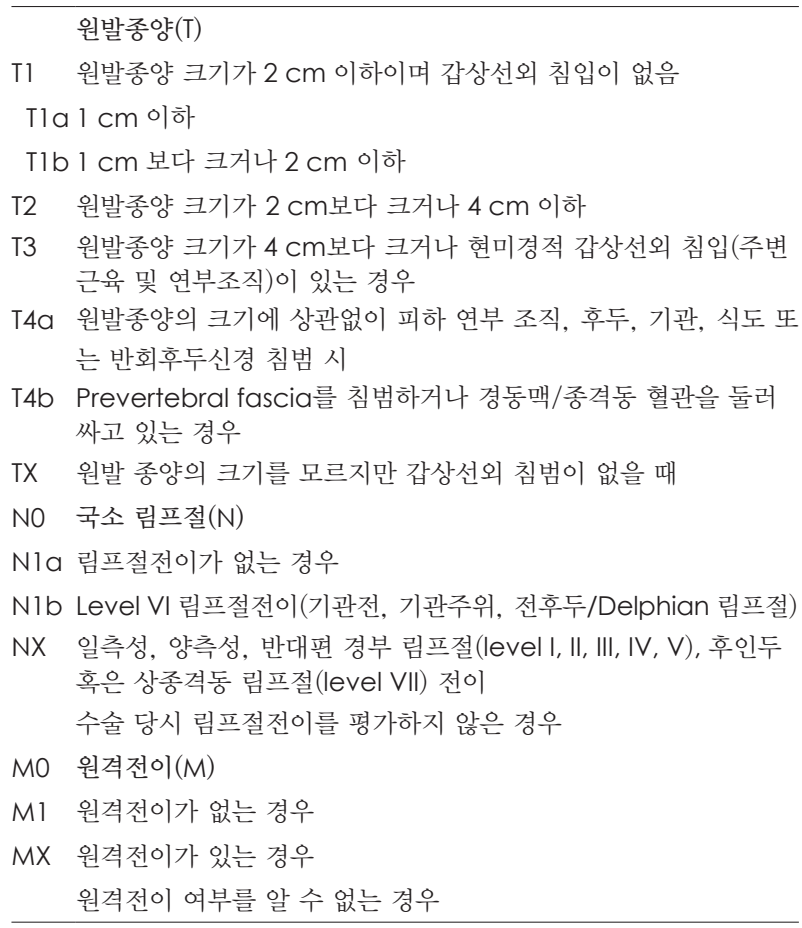

Table 4. TNM classification system for differentiated thyroid carcinoma

\begin{tabular}{llll}
\hline & 45세 미만 & & \\
\hline Stage I & Any T & Any N & M0 \\
Stage II & Any T & Any N & M1 \\
& 45세 이상 & & \\
Stage I & T1 & NO & M0 \\
Stage II & T2 & NO & MO \\
Stage III & T3 & NO & MO \\
& T1-T3 & N1a & MO \\
Stage IVA & T4a & NO, N1a & MO \\
& T1-T4a & N1b & MO \\
Stage IVB & T4b & Any N & MO \\
Stage IVC & Any T & Any N & Ml \\
\hline
\end{tabular}

갑상선암에서는 $\mathrm{AJCC} / \mathrm{UICC}$ 병기가 몇몇 추가적인 독립적 예후인자를 고려하지 않기 때문에, 일부 환자는 잘못 분류 될 가능성이 있다. 보다 정확하게 위험인자를 이용하여 예 후에 따라 환자군을 나누기 위해 CAEORTC, AGES, AMES, U of C, MACIS, OSU, MSKCC, NTCTCS 등, 수많은 분류 시스템이 개발되었다. ${ }^{70,113-117)}$ 예후인자들 중 가 장 강력한 것으로는 원격전이 여부, 환자의 연령, 종양의 국 소 진행 정도 등이다. 각각의 분류는 저 위험군에 속하는 대부분의 환자(70 85\%)를 구별하게 해주며, 이로써 이들 에게 덜 강력한 추적관찰 및 치료를 시행할 수 있게 한다.

- 질병의 사망률 예측과 암등록에 대한 필요성 때문에 AJ$\mathrm{CC} / \mathrm{UICC}$ 병기 분류는 모든 갑상선분화암 환자에게 권장한 다. 수술 후 임상적, 병리적 병기결정은 예후의 예측과 추후 치료방침의 결정을 위해서도 유용하다. 권고수준 2

잔여 병소의 존재나 재발의 위험에 따른 환자의 분류(저위 험군, 중간위험군, 고위험군)

$\mathrm{AJCC} / \mathrm{UICC}$ 병기 분류는 사망을 예측하는 분류이므로 추적 검사의 강도를 판단하는 용도에 사용하기는 부적절하 며, 재발 위험도에 따른 환자의 분류는 다음과 같은 분류 기준에 따른다. ${ }^{3)}$

\section{저위험군}

국소 또는 원격 전이가 없고, 2) 수술로 육안적 병소가 모두 제거되었으며, 3) 주위 조직으로의 침윤이 없고, 4) 나쁜 예후 를 갖는 조직형(키큰 세포 변이종, 원주형세포 변이종, 미만 성 경화 변이종, 고형 변이종)이 아니며, 5) 방사성요오드 잔 여갑상선제거술 이후에 시행한 첫 번째 치료 후 전신스캔에 서 갑상선 부위(thyroid bed) 외에는 섭취가 없는 경우로 정 의한다. ${ }^{92,118,119}$ 
중간위험군

1) 수술 후 병리조직검사에서 갑상선 주위 연조직으로 현 미경적 침윤 소견이 있거나, 2) 중앙 림프절의 전이가 있거 나, 첫번째 방사성요오드 잔여 갑상선제거술 후 전신스캔에 서 갑상선 부위 이외의 섭취가 있는 경우, 3) 원발종양이 나 쁜 예후를 갖는 조직형이거나, 혈관 침범 소견이 있는 경우 이다. ${ }^{120-122)}$

고위험군

1) 종양이 육안적으로 주위 조직을 침범하였거나, 2) 종양 을 완전히 제거하지 못하였거나, 3) 원격전이가 있는 경우 또는 4) 방사성 요오드 전신스캔 소견에 비하여 혈중티로글 로불린 농도가 높은 경우이다. ${ }^{123,124)}$

\section{갑상선절제술 후 방사성요오드 잔여갑상선제거술}

갑상선절제술 후 방사성요오드 투여로 잔여갑상선조직을 제거하는 목적은 1) 잔여갑상선조직을 완전히 제거함으로써 재발 병변의 발견과 초기 병기 결정을 용이하게 하고, 2) 보조 치료(adjuvant therapy)로써 국소적 재발의 위험을 줄이고 의심스러우나 규명되지 않은 전이 병소를 파괴하여 질병사 망률을 줄이며, 3) 알려진 지속적으로 남아 있는 병변을 치 료하기 위함이다. ${ }^{65.66)}$ 그러나 사망률이 낮은 저위험군의 갑 상선유두암에서는 이러한 효과를 관찰하지 못하였다는 보 고도 있다.

- 방사성요오드 잔여갑상선제거술은 다음의 환자에게 권장 한다.

1) 원격 전이가 있거나, 육안적으로 갑상선 주위 조직으로 종 양 침윤이 있거나, 원발 종양의 크기가 $4 \mathrm{~cm}$ 를 초과하는 모든 환자. 권고수준 1

2) 갑상선에 국한된 종양의 크기가 $1 \sim 4 \mathrm{~cm}$ 이거나, 림프절 전이가 있거나, 환자의 나이, 종양의 크기, 림프절 상태, 조직 형을 같이 고려 하여 중간 또는 고위험군인 환자의 경우. 권 고수준 2

3) 종양의 크기가 $1 \mathrm{~cm}$ 미만이나 병소가 여러 개 이거나 중 간 또는 고위험군인 환자. 권고수준 3

방사성요오드 투여 전에 갑상선호르몬을 중단하는 방법 방사성요오드 투여로 잔여갑상선을 제거할 때, 전신스캔 및 혈청 $\mathrm{Tg}$ 농도를 측정을 이용한 추후의 경과 관찰 등에는 $\mathrm{TSH}$ 자극이 필요하다. 후향적 연구에 의하면 혈청 TSH 농 도가 $30 \mathrm{mU} / \mathrm{L}$ 이상일 경우 종양의 방사성요오드 섭취가 증
가함이 관찰되었다. ${ }^{131)}$ 이에 반해, 외인성 $\mathrm{TSH}$ 를 1 회 주사할 경우에는 TSH 농도가 51 82 mU/L 사이일 때 갑상선 세포 에 대한 최대 자극효과를 관찰할 수 있었다. ${ }^{132,133)}$ 내인성 TSH 농도는 1) levothyroxine $\left(\mathrm{LT}_{4}\right)$ 을 levotriiodo-thyronine $\left(\mathrm{LT}_{3}\right)$ 으로 변경하여 2 4주간 지속한 후 2주간 $\mathrm{LT}_{3}$ 를 중 단하거나, 또는 2) 3 주간 $\mathrm{LT}_{4}$ 를 중단하여 증가시킬 수 있 다. ${ }^{133-142)}$

- 방사성요오드 치료나 전신스캔을 시행하는 환자는 최소한 3 주간 $\mathrm{LT}_{4}$ 를 중단하거나 2 4주간 $\mathrm{LT}_{3}$ 로 변경한 후 $\mathrm{LT}_{3}$ 를 2주간 중단한 후 TSH 농도를 측정하여 적절한 검사/치료 시기(TSH 30 $\mathrm{mU} / \mathrm{L}$ 이상)를 결정할 수 있다. 방사성요오드 투여 후 2 3일에 는 갑상선호르몬 치료를 다시 시작하도록 한다 $\left(\mathrm{LT}_{3}\right.$ 를 7 10 일간 같이 쓸 수도 있다). 권고수준 2

방사성요오드 치료 전 전신스캔 촬영

방사성요오드 전신스캔은 요오드를 섭취하는 갑상선조직 의 존재 여부에 대한 정보를 제공한다. 전신스캔에서 잔여 정 상 갑상선조직의 양이 많을 때에는 대부분의 요오드가 정상 갑상선조직에 의해 섭취되기 때문에, 국소 림프절, 상부 종 격동 등의 국소적 갑상선암이나 원격전이된 갑상선암을 놓 칠 수 있으며 이는 검사의 민감도를 감소시킨다. ${ }^{143)}$ 최근 전 신스캔 결과가 잔여갑상선제거술의 시행여부의 결정에 미치 는 영향이 적고, I-131에 의한 정상 갑상선조직이나 갑상선 암의 기절효과(stunning)를 고려하여 방사성 요오드 치료 전 전신스캔을 시행하지 않는 경향이 증가하고 있다. ${ }^{144)}$ 한 편 I-123과 I-131 사이의 비교연구에서 이들의 종양 발견에 대한 효과는 매우 비슷함이 밝혀져 있지만, 적절한 I-123의 용량과 투여 이후 전신스캔 촬영의 시기 등은 알려져 있지 않 다. ${ }^{145)}$ 또한 I-123은 고가이고, 일반적으로 구하기 어려우며 반감기가 짧아서 $\left(\mathrm{T}_{1 / 2}=13\right.$ 시간) 다루기 어려운 단점이 있다. ${ }^{146)}$

- 방사성요오드 치료 전 전신스캔이나 갑상선 부위 섭취율의 측정은 수술기록이나 경부 초음파로 잔여 갑상선의 양을 정확 하게 확인할 수 없을 때, 검사 결과로 인해 치료 방침이나 방 사성요오드 치료 용량이 달라질 때에는 유용할 수 있다. 검사 를 시행할 경우에는 $1-123$ 이나 $2 \mathrm{mCi}(74 \mathrm{MBq})$ 전후의 저용량 1-131을 사용하고, 치료 용량은 진단 용량이 투여되고 72시간 이내에 투여하는 것이 적절하다. 권고수준 3

방사성요오드 잔여갑상선제거술에서 I-131의 투여용량

잔여갑상선제거술의 성공은 일반적으로 이어서 시행하는 진단적 전신스캔에서 육안으로 방사성요오드 섭취를 확인 
할 수 없거나 $\mathrm{TSH}$ 자극하에 혈청 $\mathrm{Tg}$ 가 측정되지 않는 것으 로 정의한다. 30 100 mCi의 I-131은 대체로 비슷한 잔여 갑상선제거의 성공률과 재발율을 보인다. ${ }^{147-150)}$ 소아 환자에 서는 환자의 몸무게나 체표면적에 따라서 용량을 조절하는 것이 선호된다.

- 성공적인 잔여갑상선 제거를 달성하는데 필요한 최소의 용 량(30 100 mCi, 1.1 3.7 GBq)(특히 저위험군의 환자에서는) 을 이용하도록 한다. 권고수준 2

- 현미경적 잔여 병소가 의심되거나 확인되었을 경우, 혹은 예후가 나쁜 조직형(키큰세포 변이종, 원주형세포 변이종, 미 만성 경화 변이종, 고형 변이종)일 경우 고용량(100 200 $\mathrm{mCi}, 3.7 \sim 7.4 \mathrm{GBq})$ 이 적절할 수 있다. 권고수준 3

방사성요오드 투여와 재조합 인간 갑상선자극호르몬(rhTSH, Thyrogen $^{\mathrm{TM}}$ )

갑상선기능저하 상태를 견디지 못하거나 내인성 $\mathrm{TSH}$ 가 충 분히 상승될 수 없는 대부분 환자에서 잔여갑상선제거술은 $\mathrm{rhTSH}$ 의 투여로 성공적으로 달성할 수 있다. ${ }^{151,152)}$ 전향적인 무작위배정 연구(prospective randomized study)에서 100 $\mathrm{mCi}$ 방사성요오드를 이용한 잔여갑상선제거술을 위한 준비 로 갑상선호르몬 중지와 $\mathrm{rhTSH}$ 자극은 둘 다 효과적인 것 을 보고하였다. rhTSH는 미국, 유럽 등 여러 나라에서 잔 여갑상선제거술을 위한 사용이 승인되었다. ${ }^{153-156)}$

- 방사성요오드 잔여갑상선제거술을 위하여 $\mathrm{LT}_{4}$ 중단이나 $\mathrm{rhTSH}$ 자극을 모두 이용할 수 있다. 권고수준 1

방사성요오드 투여 전 저요오드 식이

방사성요오드 치료의 효과는 갑상선 조직에 도달하는 방 사선량에 달려 있다. 방사성요오드 투여 전에 유효 방사선 량의 증가를 위하여 저요오드 식이(하루 $50 \mu \mathrm{g}$ 미만)와 요 오드의 오염을 줄이기 위한 간단한 권고들이 환자에게 권장 된다. ${ }^{157-159)}$ 저요오드식이의 적절한 기간에 대한 연구보고는 국가별로 다르며 이는 식이를 통한 요오드 섭취량이 국가별 로 다른데 기인한 것으로 여겨진다. 한국과 같이 식이를 통 한 요오드섭취량이 높은 국가에서는 2주 이상이 권장되기 도 한다. ${ }^{160-162)}$ 요오드의 섭취원으로서 식이 이외에 약물에 포함된 요오드도 있다. 약물에 의한 요오드 섭취가 치료에 방 해가 되지 않도록 미리 점검하는 것이 권장된다. 그러나 저요 오드 식이를 적절히 수행했는지는 파악하기가 힘들고, 요 오드를 포함한 약물은 다양하여 사전 점검에서 누락될 수도 있으므로 방사성 요오드 치료 전 소변 요오드 배설량을 측
정함으로써 체내 요오드량이 치료에 충분할 만큼 감소되었 는지 판단하여 치료 일정을 결정하는데 도움을 받을 수도 있다. ${ }^{159)}$

- 방사성요오드 잔여갑상선제거술 준비를 위해 1 2주의 저 요오드 식이가 추천된다. 권고수준 2

방사성요오드 치료 후 전신스캔의 촬영

방사성요오드 치료 후 전신스캔은 원격전이의 진단을 위 하여 방사성 요오드를 투여하고 대략 1 주 내외에 시행된다. 진단 스캔과 비교하여 치료 후 전신 스캔에서는 10 26\%의 전이 병소가 추가로 발견되는데, 새로운 비정상적 요오드섭 취는 경부, 폐, 종격동에서 가장 흔하게 발견되었고, 이러한 새로운 병변은 약 $10 \%$ 의 환자에서 병기에 영향을 주거나 9 $15 \%$ 에서 치료 방침에 영향을 준 것으로 보고되었다. ${ }^{163-165)}$ I-131 단일 광자방출전산화 단층촬영(single photon emission computed tomography(SPECT)/CT 융합영상은 잔 여 갑상선제거술 후 병소를 더 잘 국소화할 수 있다. ${ }^{161)}$

- 방사성요오드갑상선제거술후에는 치료 후 전신스캔이 권장 된다. 촬영 시기의 결정에 대해 발표된 근거자료는 부족하지만, 일반적으로 투여 후 2 10일 사이에 시행하고 있다. 권고수준 2

\section{$\mathrm{TSH}$ 억제치료의 역할}

갑상선분화암은 세포막에 TSH 수용체를 가지고 있고, $\mathrm{TSH}$ 자극에 반응하여 세포성장이 증가한다. 생리적 용량 이 상의 고용량의 갑상선 호르몬제 $\left(\mathrm{LT}_{4}\right)$ 를 투여하여 $\mathrm{TSH}$ 분비 를 억제하여 갑상선암의 재발률을 감소시킨다. ${ }^{75,166)}$

\section{적절한 초기 TSH 억제치료}

후향적 연구들에 의하면 TSH를 $0.1 \mathrm{mU} / \mathrm{L}$ 미만으로 억 제시킬 경우 고위험군 환자의 예후를 향상시키지만, ${ }^{167)}$ 저위 험군에서는 TSH 억제치료의 확립된 이득이 없다. TSH 억 제치료의 부작용으로는 불현성 갑상선중독증, 허혈성 심질 환의 악화, 심방세동 위험의 증가, 폐경 후 골다공증 위험 증 가 등이 있다. ${ }^{168)}$

- 고위험군과 중간위험군의 갑상선암 환자는 처음부터 혈청 $\mathrm{TSH}$ 농도를 $0.10 \mathrm{mU} / \mathrm{L}$ 미만으로 유지하여야 하는 반면, 잔여 갑상선제거술을 시행 받지 않은 환자를 포함한 모든 저위험군 환자는 혈청 TSH 농도를 $0.10 \sim 0.50 \mathrm{mU} / \mathrm{L}$ 사이에 유지하는 것을 권장한다. 권고수준 2 


\section{추가적인 외부 방사선조사나 항암제치료}

\section{외부 방사선조사}

외부 방사선조사는 국소적으로 진행되었으나 절제가 불 가능한 병소의 증상완화 치료 등에 가끔 사용된다. ${ }^{169)}$ 그러 나 외부 방사선조사가 적절한 수술과 방사성 요오드 치료 후 경부에서의 재발을 감소시킬 수 있는지에 대해서는 확실 하지 않다.

- 외부 방사선조사는 수술할 당시 육안적으로 갑상선 밖으로 병소가 진행 되어 미세병소가 남아있을 가능성이 높은 45세 이상의 환자, 추가적인 수술이나 방사성요오드 치료로 잘 낫 지 않을 것 같은 육안으로 보이는 잔여 병소가 있는 환자에게 고려한다. 권고수준 2

\section{항암화학요법}

갑상선분화암의 치료에 보조적(adjuvant) 항암제 사용을 정당화하는 자료는 없다. 국소적으로 진행된 일부 환자에서 방사선치료를 하는 경우 사용을 고려할 수 있다.

- 갑상선분화암 환자에서 보조적인 항암제의 일상적 사용에 대한 역할은 없다. 권고수준 1

\section{갑상선분화암의 장기 치료 및 추적}

\section{장기 치료 및 추적의 목표 및 의의}

장기 추적의 주 목적은 질병이 일단 완치된 환자에서 재발 여부를 정확하게 찾아내는 것이다. 잔여 혹은 재발 병소를 갖고 있는 환자에게는 완치를, 또는 장래의 이환율이나 사 망률을 낮추는 것을 목표로 치료하며, 그것이 불가능한 경 우에는 종양 부하를 감소시키거나 성장을 억제하는 보조적 인 치료를 한다. 갑상선전절제술 또는 갑상선근전절제술과 방사성 요오드 잔여갑상선 제거술을 시행 받은 환자에서 '잔여 병소 없음'의 정의는 다음의 조건을 모두 만족하는 경 우를 칭한다. 즉, 1) 임상적으로 종양이 발견되지 않고, 2) 진 단 영상에서 종양이 발견되지 않으며(첫 번째 치료 후 전신 스캔 또는 최근의 진단적 전신스캔에서 갑상선 부위 이외의 섭취가 없거나 경부 초음파검사에서 음성), 3) 항 $\mathrm{Tg}$ 항체가 없는 상태에서 측정한 혈청 $\mathrm{Tg}$ 농도가 $\mathrm{TSH}$ 억제 상태(이 하, $\mathrm{TSH}-$ 억제 $\mathrm{Tg}$ )와 $\mathrm{TSH}$ 자극 상태(이하, $\mathrm{TSH}-$ 자극 $\mathrm{Tg}$; $\mathrm{T} 4$ 복용 중단 방법과 rhTSH-유도 방법 총칭) 모두에서 측 정되지 않는 경우이다.

\section{갑상선분화암의 추적에서 혈청 $\mathrm{Tg}$ 농도 측정의 의의}

혈청 $\mathrm{Tg}$ 농도의 측정은 갑상선전절제술과 방사성요오드 를 이용해 잔여 갑상선을 제거한 경우 잔여 갑상선암을 발 견하는데 있어서 민감도와 특이도가 높다. 특히 갑상선호르 몬 투여 중지 후 또는 rhTSH 투여 후 측정한 혈청 $\mathrm{Tg}$ 농도 는 잔여 갑상선암 발견에 있어 가장 예민한 검사법이다. ${ }^{170)}$ 종양이 작을 때에는 $\mathrm{TSH}$ 가 억제된 상태에서 혈청 $\mathrm{Tg}$ 농도 를 측정하면 잔여 병소를 찾아내지 못할 수 있다. ${ }^{118)}$ 또한 $\mathrm{TSH}$ 를 자극한 경우에도 혈청에 항 $\mathrm{Tg}$ 항체가 있거나, 드물 지만 종양 세포에서 $\mathrm{Tg}$ 를 생산하거나 분비하는 능력이 떨 어진 경우 상당한 양의 종양이 있어도 혈청 $\mathrm{Tg}$ 농도 측정으 로 종양을 발견해내지 못할 수 있다. ${ }^{171}$

갑상선전절제술 또는 갑상선근전절제술과 방사성요오드 를 이용한 잔여 갑상선 제거를 시행 받은 저위험군 환자(실 제 수술 환자의 $85 \%$ 에 해당)의 초기 추적 검사는 주로 갑 상선호르몬 투여 중 $(\mathrm{TSH}-$ 억제)의 혈청 $\mathrm{Tg}$ 농도 측정과 경 부 초음파 검사로 하며, $\mathrm{TSH}$-억제 $\mathrm{Tg}$ 농도가 음성인 경우 에는 $\mathrm{TSH}$-자극 $\mathrm{Tg}$ 농도를 측정 한다. ${ }^{118)}$

일반적으로 $\mathrm{rhTSH}$ 자극 후의 혈청 $\mathrm{Tg}$ 농도가 $2 \mathrm{ng} / \mathrm{mL}$ 이상인 것을 기준으로 하면 잔여 병소를 가진 환자를 예민 하게 찾아낼 수 있는 것으로 알려져 있다. ${ }^{172-177)}$ 그러나 같은 시료로 측정을 하여도 $\mathrm{Tg}$ 측정치가 실험실마다 다르므 로, ${ }^{178)} \mathrm{Tg}$ 기준치는 기관 또는 실험실마다 다를 수 있다. $\mathrm{Tg}$ 측정 오차를 줄이는 데에 CRM-457 international stan$\mathrm{dard}$ 를 사용하는 것이 도움이 될 수 있다. 한편, 항 $\mathrm{Tg}$ 항체 는 갑상선암 환자의 $25 \%$ 에서, ${ }^{179)}$ 일반인의 $10 \%$ 에서 ${ }^{180)}$ 발견 되는데, 항체가 존재하면 면역계수측정법을 이용한 $\mathrm{Tg}$ 측 정시 $\mathrm{Tg}$ 농도가 실제보다 낮게 측정된다. ${ }^{181)}$

경부 림프절에 작은 전이 병소만 있거나 분화도가 낮은 갑상선암의 경우 혈청 $\mathrm{Tg}$ 의 진단 예민도는 떨어진다. ${ }^{124,182)}$ $\mathrm{TSH}-$ 억제 또는 $\mathrm{TSH}-$ 자극에 관계없이 혈청 $\mathrm{Tg}$ 농도가 지 속적으로 증가하면 임상적으로 유의한 병소의 존재를 암시 한다. ${ }^{183,184)}$

- 갑상선전절제술 또는 갑상선근전절제술과 방사성요오드를 이용한 잔여 갑상선 제거를 시행 받은 갑상선분화암 환자의 추적에서 혈청 $\mathrm{Tg}$ 농도를 $6 \sim 12$ 개월 간격으로 측정한다(가능 하면 CRM-457 표준으로 보정된 방법을 같은 실험실 에서 같 은 측정법으로). $\mathrm{Tg}$ 농도를 측정할 때마다 항 $\mathrm{Tg}$ 항체를 동시 에 정량적 방법으로 측정한다. 권고수준 1

- 갑상선근전절제술 미만의 수술을 받았거나, 갑상선전절제술 을 받았으나 방사성요오드를 이용한 잔여갑상선제거를 시행 
하지 않은 경우의 추적에 있어서 도 주기적인 혈청 $\mathrm{Tg}$ 농도 측정 이 도움이 될 수 있다. 이 경우 잔여 및 재발 병소를 암시하는 $\mathrm{Tg}$ 기준치는 알려져 있지 않으나, $\mathrm{Tg}$ 농도가 시간 경과에 따라 증가 하는 경우 재발을 의미할 수 있다. 권고수준 2

- 방사성요오드를 이용한 잔여갑상선제거술을 시행 받은 '저 위험군'의 갑상선 분화암 환자에서 치료 1 년 이내에 시행한 $\mathrm{TSH}-$ 억제 $\mathrm{Tg}$ 농도 및 경부 초음파 검사가 음성인 경우, 잔여 갑상선 제거 후 12 개월 되는 시점에 $\mathrm{TSH}-$ 자극 $\mathrm{Tg}$ 농도를 측 정한다. $\mathrm{TSH}$-자극 $\mathrm{Tg}$ 농도가 음성인 경우 추후 자극 검사의 시행이 필요한지, 또는 어느 시점에 시행해야 하는지는 아직 불분명하다. 권고수준 1

- 방사성요오드를 이용한 잔여갑상선제거술을 시행 받고 경 부초음파 검사 및 $\mathrm{TSH}$-자극 $\mathrm{Tg}$ 가 음성인 저위험군은 이후 $\mathrm{TSH}-$ 억제 $\mathrm{Tg}$ 와 경부초음파를 매년 시행하며 경과관찰을 할 수 있다. 권고수준 2

\section{갑상선분화암환자의 추적에서 진단적 전신 방사성요오드 스캔 및 초음파검사}

\section{진단적 방사성요오드 전신스캔}

진단적 방사성요오드 전신스캔을 환자의 추적에 이용할 때 두 가지 사항이 고려되는데, 기절효과(stunning)와 정확 도이다. 환자 추적에서 진단적 전신스캔은 정상 갑상선조직 이 없거나 거의 없어야 진단 검사로 가장 유용하다. 간혹 진 단 스캔에서 발견되지 않던 병소가 치료 목적의 고용량 I-131 투여 후 촬영한 전신스캔에서 발견될 수 있다. ${ }^{185-188)}$

- 방사성요오드 잔여갑상선제거술을 시행 받고 첫 번째 치료 후 전신스캔을 시행한 '저위험군' 환자에서는, $\mathrm{TSH}$-억제 $\mathrm{Tg}$ 가 측정되지 않고(동시에 항 $\mathrm{Tg}$ 항체 음성), 경부 초음파검사가 음성이라면 추적 관찰 중에 진단적 방사성 요오드 전신스캔을 일상적으로 시행할 필요는 없다. 권고수준 1

- 방사성요오드로 잔여갑상선제거술을 시행한 '중간위험군' 또는 '고위험군' 환자에서는 6 12개월 후에 시행하는 진단적 전신스캔이 유용할 수 있다. 이 때 진단적 전신스캔은 |-123 또는 저용량의 I-131을 이용하여 시행하여야 한다. 권고수준 3

\section{경부 초음파검사}

경부 초음파검사는 갑상선분화암 환자에서 경부 전이를 발견하는데 매우 예민한 검사이며, ${ }^{189)} \mathrm{TSH}$-자극 $\mathrm{Tg}$ 가 음
성인 환자에서도 전이 병소를 발견할 수 있다. ${ }^{182)}$

경부 초음파검사 소견상 림프절 전이가 의심되는 경우에 는 $\mathrm{FNAC}$ 와 세침 내용물에 대한 $\mathrm{Tg}$ 검사가 진단에 도움이 된다. ${ }^{190)}$ 그러나, 크기가 작은 림프절의 경우(직경이 $5 \sim 8 \mathrm{~mm}$ 미만)에는 $\mathrm{FNAC}$ 후 비진단적인 결과를 얻을 가능성이 높 고, $\mathrm{FNAC}$ 로 림프절 전이가 확인이 되더라도 크기가 작아 서 수술 시 전이된 림프절을 발견하지 못할 가능성 등이 있 으므로, 림프절 절제술에 따른 합병증 가능성 등을 함께 고 려하여, 바로 $\mathrm{FNAC}$ 를 시행하지 않고 면밀한 추적관찰을 시행하면서, 크기가 증가하거나, 경부의 주요 주변 기관으로 의 침범이 의심이 될 때에 $\mathrm{FNAC}$ 를 시행할 수도 있다. 그러나, 크기가 작은 전이 림프절의 수술 시기에 따른 예후 및 사망 률에 대해서는 아직까지 보고된 연구 결과는 없다.

- 수술 후에는 갑상선부위와 중앙, 측경부 림프절 구획을 평 가하기 위해 경부 초음파 검사를 수술 후 6 12개월에 시행하 며, 이후 환자의 재발 위험성과 $\operatorname{Tg}$ 수준에 따라 매년 시행할 수 있다. 권고수준 2

- 경부 초음파검사에서 초음파소견상 전이가 의심되는 림프 절을 동반한 경우, 초음파 유도하 FNAC를 시행하며, 이때 세 침내용물의 세척용액에서 $\mathrm{Tg}$ 를 같이 측정하면 진단에 도움을 받을 수 있다. 권고수준 2

- 초음파소견상 의심스러운 소견을 보이나 직경이 $5 \sim 8 \mathrm{~mm}$ 미만인 림프절은 $\mathrm{FNAC}$ 를 시행하지 않고 경과를 관찰할 수 있으나, 크기 증가 및 경부의 주요기관에 대한 침범이 발생하 는지에 대한 주의깊은 경과 관찰이 필요하다. 권고수준 3

\section{F-18 FDG-PET 스캔}

최근에 F-18 FDG-PET은 $\mathrm{Tg}$ 양성, 방사성요오드스캔 음 성 환자들의 병소 국소화 뿐만 아니라 다른 적응증에서도 이용될 수 있다. ${ }^{191,192)}$

- F-18 FDG-PET 스캔은 혈청 Tg가 양성이나 방사성요오 드 스캔 음성인 경우 병소의 국소화에 있어서 증명된 역할 외 에 다음과 같은 경우에 적용할 수 있다. 권고수준 3 1) 분화도가 나쁜(poorly differentiated) 갑상선암 또는 침습성 Hürthle 세포암의 초기 병기 결정의 일환으로, 특히 영상 검사 에서 다른 병변의 증거가 있거나 혈청 $\mathrm{Tg}$ 수치가 상승된 경우 2) 전이 병소가 있는 환자에서 급속한 병의 진행이나 암에 의 한 사망의 위험이 높은 환자를 식별하는 예측 방법으로 쓰고 자 하는 경우 
3) 전이성 또는 국소 침습성 병변의 전신 또는 국소 치료 후 치료 반응을 평가하고자 하는 경우

저위험군 환자에서 초기 병기 결정과 추적관찰에 $\mathrm{FDG}-$ $\mathrm{PET}$ 을 필요로 하는 경우는 매우 드물다. 또한 염증성 림프 절, 봉합육아종(suture granuloma), 근육 의 섭취 등이 흔한 위양성의 원인이 되므로, $\mathrm{FDG}-\mathrm{PET}$ 양성인 병변은 조직 또 는 세포학적 확인이 필요하다. ${ }^{192)}$

\section{갑상선분화암의 장기 추적에서 갑상선호르몬 억제치료}

최근의 여러 연구들을 종합한 결과 갑상선호르몬 억제치 료를 시행한 경우 주요 유해사례의 발생이 감소되는 것으로 밝혀졌다. ${ }^{166)} \mathrm{LT} 4$ 에 의한 TSH 억제의 적절한 수준은 아직 까지 알려져 있지 않다. 한 연구에서 $\mathrm{TSH}$ 농도가 $1 \mathrm{mU} / \mathrm{L}$ 이상일 때보다 지속적으로 $0.05 \mathrm{mU} / \mathrm{L}$ 이하로 억제되어 있 을 경우 무병생존기간이 더 길었으며, 다변량 분석에서 TSH 억제 정도가 재발의 독립적 예측 인자였다. ${ }^{167)}$ 반면 다른 대 규모 연구에서는 병기, 환자의 연령, 방사성요오드 치료여부 가 각각 질환의 진행을 독립적으로 예측하는 인자로 밝혀졌 고 TSH 억제 정도는 연관이 없는 것으로 밝혀졌다. ${ }^{75)}$ 또 다 른 연구에서는 $\mathrm{LT}_{4}$ 치료 동안 $\mathrm{TSH}$ 를 $0.5 \mathrm{mU} / \mathrm{L}$ 미만으로 억제하는 경우보다 정상범위로 유지하였을 때 평균 $\mathrm{Tg}$ 농도 가 더 높았으나 이러한 현상은 국소 또는 원격 재발이 있는 경우에만 관찰되었다. ${ }^{193)}$

- 갑상선암 잔여 병소를 가지고 있는 환자에서 혈청 TSH 농 도는 특별한 금기사항이 없는 한 계속 $0.1 \mathrm{mU} / \mathrm{L}$ 미만으로 유 지할 것을 권고한다. 권고수준 2

- 혈청 $\mathrm{Tg}$ 검사와 임상적으로 갑상선암이 발견되지 않으나, 재발의 가능성이 높은 고위험군에서는 수술 후 5 10년 동안 혈청 TSH 농도를 $0.1 \sim 0.5 \mathrm{mU} / \mathrm{L}$ 사이로 유지할 것을 권고한 다. 권고수준 3

- 임상적으로 갑상선암이 발견되지 않고, 재발의 가능성이 낮은 저위험군에서는 TSH 농도를 0.3 2 $\mathrm{mU} / \mathrm{L}$ 사이로 유지 할 것을 권고한다. 권고수준 3

- 방사성요오드 잔여갑상선제거술을 시행 받지 않고 재발 없 이 경과관찰 중인 경우에는, 경부초음파 소견과 $\mathrm{TSH}-$ 억제 $\mathrm{Tg}$ 가 음성이면, TSH 농도를 $0.3 \sim 2 \mathrm{mU} / \mathrm{L}$ 사이로 유지하는 것 이 가능하다. 권고수준 3

\section{전이 병소를 가진 갑상선분화암 환자의 치료}

전이 병소에 대한 치료방법은 국소 병변의 수술적 제거, 방
사성요오드 치료, 외부 방사선조사, 주의깊은 추적관찰(안정 적이고 무증상인 경우), 시험적 항암치료 순으로 선호된다. 일 부 환자에서 고주파 제거술, ${ }^{194)}$ 알코올 주입술, ${ }^{195)}$ 항암색전 술 ${ }^{196)}$ 등이 치료에 도움이 될 수 있다.

\section{국소 전이의 수술적 치료}

수술은 원격전이가 없는 환자에서 국소 및 경부 재발의(예 를 들어 경부 림프절 또는 경부의 연부 조직 종양) 우선적인 치료법이다. 단기간의 추적 결과를 보면 수술적 치료로 약 $1 / 3-1 / 2$ 의 환자가 완치된다. ${ }^{197)}$ 촉진되지 않는 림프절도 초 음파나 다른 영상 진단법으로 확인되면 수술적 절제를 고려 해야 한다. 일반적으로 현미경적 림프절전이는 영상검사에 서 나타나는 것보다 더 광범위하기 때문에, 선택적인 림프절 절제나 알코올 주입 치료보다는 중요 구조물들을 보존하면 서 잔여 및 재발 병변이 있는 구획을 완전 절제하는 수술(예 를 들어 일측 중앙 림프절절제술, 기능적 광범위 구역 절제 술)이 더 선호된다. ${ }^{104,198,199)}$

- 경부에 국한된 잔여 및 재발 병변을 가진 환자에서는 포괄 적 측경부 림프절절제술 또는 중앙 림프절절제술을 고려하되 침범되지 않은 중요 구조물은 보존한다. 과거에 포괄적 림프 절절제술 또는 방사선치료를 받은 경부 구획에 재발하였다면 포괄적 림프절절제술보다는 제한된 구획의 측경부 림프절절 제술 또는 중앙 림프절절제술이 합리적 선택일 수 있다. 권고 수준 2

\section{호흡기-소화기 침범 병변의 수술적 치료}

상부 호흡기-소화기를 침범한 종양은 일반적으로 수술과 함께 추가적인 방사성요오드 치료를 시행하고 추가적으로 외부 방사선조사를 고려한다. ${ }^{200,201)}$ 환자의 예후는 기능은 보존하면서 확인된 종양을 완전히 제거할 수 있느냐에 달려 있는데, 기관 혹은 식도의 표면에 있는 종양을 제거하는 것 부터 침범이 깊을 경우 기관 절제와 문합 ${ }^{202-204)}$ 혹은 식도인 두절제술 등의 적극적인 수술기법까지 다양하다. 근치적 수 술이 불가능한 환자의 경우 기관 스텐트나 기관 절개술 등 으로 삶의 질을 향상시킬 수 있다. 레이저 치료는 기도폐색 이나 기도출혈을 치료하거나, 근치적 혹은 고식적 치료를 위 한 예비단계로 이용될 수 있다. ${ }^{201)}$

- 상부 호흡기-소화기를 침범한 종양은 기술적으로 가능하 다면, 병소를 제거하는 수술과 더불어 방사성요오드 치료를 시행하고 추가적으로 외부 방사선 조사를 고려한다. 권고수 준 2 
국소 혹은 원격전이 병소에 대한 방사성요오드 치료

병소가 크거나 초음파, CT 스캔 혹은 MRI와 같은 해부학 적 영상에서 수술로 절제 가능한 병소가 있는 경우 수술을 하게 되지만, 그 외의 경우에는 진단스캔에서 국소 림프절 전이가 발견되면 일반적으로 방사성 요오드 치료가 이용된 다. 국소 림프절전이 또는 소화기-호흡기 침윤 병소의 수술 적 제거 후에도 잔여 병소가 있거나 의심되는 경우 수술 후 부가적으로 방사성요오드 치료를 한다.

많은 환자에서 방사성요오드 치료의 효과가 입증되었으 나 최적의 용량에 대하여는 아직 논란이 있다. ${ }^{205)}$ 방사성요 오드 치료에는 3 가지 방법이 있는데, 1) 경험적인 고정 용량 을 투여하는 방법, 2) 혈액과 체내 방사선량을 측정하여 상한 치에 의해 결정하는 방법, 3) 그리고 정량적 종양 방사선량 측정에 의한 방법 ${ }^{172)}$ 등이다. 용량결정에서 방사선량 측정법 은 제한된 경우에 사용하는데 원격 전이가 있거나 신부전 혹 은 rhTSH 자극을 이용한 치료가 필요한 경우에 사용한다.

최대허용방사선 흡수선량(maximum tolerated radiation absorbed dose, MTRD)은 보통 혈액에 대한 선량 $200 \mathrm{cGy}$ 로 정의되는데, 다양한 용량을 사용하는 경험적 치료에서는 상당수의 환자에서 이를 초과할 가능성이 있다. ${ }^{206)}$

- 국소 혹은 원격전이 병소의 치료를 위한 방사성요오드 치 료 투여량 결정에서 경험적 고용량과 선량측정을 통한 용량 결정 중 어느 것이 더 우월한지에 대한 권고안은 아직 없다.

\section{권고수준 4}

- 경험적으로 투여하는 $\mid-131$ 용량이 $200 \mathrm{mCi}$ 를 초과하면 70세 이상의 고령의 환자에서는 최대허용방사선 흡수선량을 초과할 가능성이 있으므로 이를 피하도록 한다. 권고수준 1

방사성요오드 치료 결과에서 갑상선호르몬 중단치료와 $\mathrm{rhTSH}$ 자극치료를 비교한 무작위 시험은 아직까지 없다. 많은 증례 보고나 비무작위 시험연구들에서 rhTSH 투여 후 방사성요오드 치료를 하였을 때 일부의 환자에서 질환의 안정화 또는 호전이 있음이 알려졌다.

- 방사성요오드 치료 시 전이 병소가 있는 모든 환자에게 $\mathrm{rhTSH}$ 자극 치료를 권하기에는 아직까지 근거가 불충분하다.

\section{권고수준 3}

- rhTSH 자극 방사성요오드치료는 갑상선호르몬 중단에 의 한 갑상선기능저하증이 기저 질환을 악화시켜 위험을 초래할 수 있는 환자, 내인성 TSH의 농도를 충분히 올릴 수 없는 뇌 하수체질환을 가지고 있는 환자, 혹은 치료가 지연될 경우 심
각한 결과를 야기할 우려가 있는 환자 등 일부 선별된 환자에 게 적응이 될 수 있다. 권고수준 3

\section{폐 전이의 치료}

폐 전이의 치료 시 중요하게 고려해야 할 사항들로는 전이 병소의 크기, 방사성요오드의 섭취 정도 그리고 이전의 방사 성요오드 치료에 대한 반응, 전이 병소의 안정성 등이다. 폐섬 유화(pulmonary fibrosis)는 고용량 방사성 요오드 치료 의 드문 부작용이다. 폐섬유화가 의심되면 주기적인 폐기능 검사를 시행하고, 호흡기내과 전문의와 협진을 통하여 자문 을 구하여야 한다. 폐섬유화는 방사성 요오드로 전이 병소 를 치료하는데 제한이 된다.

- 폐 미세전이(pulmonary micrometastasis)는 방사성요오 드 치료에 반응하여 완전관해의 가능성이 높으므로 반응이 있는 한 6 12개월마다 계속 치료하여야 한다. ${ }^{173-175)}$ 권고수준 1 - 폐 미세전이 치료를 위해 투여하는 방사성요오드 투여량 은 경험적으로(100 200 mCi) 투여하거나 혹은 전신에 잔류 하는 방사선량이 48시간에 $80 \mathrm{mCi}$ 그리고 적색골수에 200 $c G y$ 로 제한되도록 방사선량측정에 의해 평가하여 투여 할 수 있다. 권고수준 2

- 방사성요오드를 섭취하는 대결절 폐전이(macronodular pulmonary metastasis)의 경우 방사성요오드로 치료하여야 하며, 객관적인 효과(병변의 크기 감소, $\mathrm{Tg}$ 감소)가 있다면 반 복해서 치료하여야 한다. 그러나 완전 관해는 흔하지 않으며 생존율 또한 낮다. 방사성요오드 용량은 경험적(100 200 $\mathrm{mCi}$ 으로 하거나 48시간에 체내 축적량이 $80 \mathrm{mCi}$ 가 되거나 적골수에 $200 \mathrm{cGy}$ 이하로 축적되도록 측정하여 투여한다. 권고수준 2

- 방사성요오드를 섭취하지 않는 폐 전이 병변은 많은 경우 에 천천히 자라므로 TSH 억제치료 등의 보존적인 치료만 시 행하면서 관찰할 수 있다. 그러나 일부 환자에서는 훙곽 내 병 소(예를 들어 기관 내 종괴에 의한 폐색이나 출혈)에 대한 증 상을 경감시키기 위한 전이 병소 절제, 기관 내 레이저 치료, 또는 보존적 외부 방사선 치료를 고려할 수 있다. 그리고 흉막 이나 심막의 삼출액의 배액 등도 고려할 수 있다. 이런 환자들 은 새로이 시도되는 치료법의 임상시험에 의뢰하는 것을 고려 할 수 있다. 권고수준 3

- 진행성이거나 증상이 있는 전이 병변이 있는 환자에 대해 서는 임상시험에 참여하도록 의뢰하는 것이 고려되어야 한다. 임상시험에 참여하지 않는 환자에 대해서는 tyrosine kinase 억제제들의 사용을 고려한다. 권고수준 2 
골 전이의 치료

골 전이 환자의 치료 결정을 할 때 고려해야 할 중요한 사 항들은 병적인 골절의 위험성(특히 무게를 많이 받는 구조 에서), 척추 병변에 대한 신경학적인 손상의 위험성, 통증의 유무, 방사성요오드 섭취 여부, 방사성요오드를 이용한 골 반전이 치료 시 방사능에 의한 골수억제 가능성 등이다.

- 증상을 유발하는 단일 골 전이 병변에 대한 완전 절제는 생존율을 증가 시키는 것으로 밝혀졌으므로(특히 45세 미만 인 경우) 적극적으로 고려하여야 한다. ${ }^{176,177)}$ 권고수준 2

- 방사성요오드를 섭취하는 골 전이에 대한 방사성요오드 치료는 생존율을 증가시키므로 치료에 포함하여야 한다. ${ }^{17.176)}$ 방사성요오드 용량은 경험적(100 200 mCi)으로 하거나 선 량을 측정하여 용량을 계산하여 투여한다. ${ }^{138)}$ 권고수준 2

- 전이성 골 병소가, 급성 종창이 될 경우 통증이나 골절, 신 경학적 합병증 발생을 유발할 것으로 예상되는 부위에 존재하 는 경우에는, 외부 방사선 치료나 TSH 자극에 의한 종양의 종창을 최소화하기 위하여 당류코르티 코이드 투여 병행을 적 극적으로 고려할 수 있다. ${ }^{207)}$ 권고수준 3

- 수술적 제거가 불가능하며 통증을 유발하는 병소에 대해 서는 방사성 요오드, 외부 방사선 치료, 동맥 색전술, ${ }^{196,208)}$ 고 주파 열치료 ${ }^{209)}$ 주기적인 pamidronate 또는 zolendronate 주사, ${ }^{210)}$ 척추성형술(vertebra-plasty) 등 ${ }^{211)}$ 여러 방법을 개별 혹은 병용 치료로 사용한다. 이 중 많은 방법들이 암에서 골 통증을 경감시키는데 효과적인 것으로 알려졌으므로, 갑상선 암 에서 사용되었다 는 보고가 없더라도 사용을 고려할 수 있 다. 권고수준 3

- 증상이 없고, 방사성요오드에 반응이 없으며, 인접 부위에 중요한 구조물이 없는 안정적인 전이성 골 병소에 대하여는 치료를 권할 만한 근거가 없다. 권고수준 4

\section{뇌 전이의 치료}

뇌 전이는 주로 고령의 환자에서 발견 당시부터 진행암인 경우가 흔하며 예후가 나쁘다. ${ }^{212)}$ 수술적 절제와 외부 방사 선 치료가 주를 이루고 있다. ${ }^{212,213)}$ 방사성요오드 치료의 효 용성을 입증하는 자료는 거의 없다.

- 중추신경계 전이 병소의 완전 절제는 생존율을 의미 있게 향상시키므로 방사성요오드 섭취 여부와 상관없이 고려된다. 권고수준 2
- 수술적 절제가 어려운 중추신경계 병변은 외부 방사선 치 료를 고려한다. 간혹 주변 뇌조직에 대한 방사능의 노출을 줄이기 위해 방사선수술(radiosurgery)과 같은 병소 표적 치 료 방법을 사용하기도 한다. 다발성 전이시 뇌와 척추 전체 에 대한 방사선 치료를 고려할 수 있다. 권고수준 3

- 만약 중추 신경계 전이가 방사성요오드를 섭취한다면 방 사성요오드 치료를 고려할 수도 있다. 방사성요오드 치료를 고려한다면 우선 외부 방사선 치료를 하고 방사성요오드 치 료 시 TSH 에 의한 종양 크기의 증가나 방사성요오드 치료 에 따른 염증 반응을 최소화하기 위해 당류 코르티코이드 투 여를 병용하는 것이 필요하다. ${ }^{207)}$ 권고수준 3

방사성요오드 치료의 합병증에 대한 치료

방사성요오드 치료는 충분히 안전한 방법으로 생각되나 이 역시 누적 용량(cummulative dose)과 관련하여 타액선 손상, 누비관 폐색, ${ }^{214)}$ 그리고 이차성 종양 등 ${ }^{215)}$ 과 같은 합 병증의 위험이 동반된다. 따라서 방사성요오드 치료에 의한 이득이 잠재적인 위험성보다 높을 경우에 사용하여야 한다. 완전히 안전한 방사성요오드 용량이란 것은 없으며 또한 꼭 필요한 경우에는 사용하면 안 되는 최대 누적 용량의 한계 또한 없다. 그러나 단일치료 용량이나 누적 용량이 높을수록 부작용의 위험성도 증가한다.

- 방사성요오드 치료 후 타액선 손상을 예방하기 위하여 사 용하는 방법들의 통상적인 사용 여부를 추천하거나 금지할 만한 증거는 불충분하다. 권고수준 4

- 구강 건조증 환자들은 치아 우식증의 위험성이 있으므로 치과 의사에게 의뢰 한다. 권고수준 3

- 누비관협착에 의하여 누액 유출이 막혔을 경우 눈물 흘림

이 심하며 감염의 가능성이 있으므로 수술적 교정을 고려한

다. 권고수준 2

\section{방사성요오드 치료에 의한 이차성 악성 종양 및 백혈병}

장기 추적을 통한 연구에서 방사성요오드 치료를 받은 갑 상선암 생존자들에서 일부 암(골 및 연조직암, 유방암, 대장 암, 타액선암, 다발성 골수종, 백혈병) 발생의 상대 위험도는 약간 증가하는 것으로 나타났으며, 위험도의 증가는 치료용 량과 밀접한 연관이 있다. ${ }^{215}$ 갑상선암이 있는 여자 환자의 경 우 유방암의 위험성이 증가하는 것처럼 보이는데, ${ }^{216)}$ 이 결과 가 선별 검사의 오류 때문인지 방사성요오드 때문인지 아니 면 다른 요인들 때문인지는 명확하지 않다. 
- 집중적인 암 검진에 대한 이점이 없으므로 모든 갑상선암 환자들에게는 일반인의 경우와 같은 권고에 따라 연령에 맞는 암 스크리닝을 하도록 권고할 수 있다. 권고수준 3

\section{방사성요오드 치료에 따른 기타 골수질환의 위험성}

발표된 자료에 의하면 방사선량이 골수에서 $200 \mathrm{cGy}$ 미 만이면 백혈구나 혈소판에 대한 영향은 경미하고 일시적이 다. ${ }^{217)}$ 그러나 지속적인 약간의 백혈구나 혈소판 수의 감소 는 여러 번 방사성요오드 치료를 받은 환자들에게 드문 것 은 아니다. 골수에 대한 방사선의 영향은 신장 기능을 포함 한 여러 요인들의 영향을 받는다.

- 치료 용량의 방사성요오드를 투여 받는 환자들에서는 전 혈구검사(CBC), 혈소판 수, 신기능에 대한 기저 검사를 시행 한다. 권고수준 3

\section{생식선 기능과 수유 중인 여성에 대한 방사성요오드의 영향}

생식선의 조직들은 혈액이나 소변, 대변 등에 의해 방사 성요오드의 방사능에 노출된다. 갑상선암으로 방사성요오 드 치료를 받은 폐경 이전의 여자들 중 20 27\%에서 일시 적인 무월경/희발월경이 4 10개월간 지속되기도 한다. 비 록 소규모 연구이기는 하지만 장기간의 불임, 유산, 선천성 태아 기형 등이 방사성 요오드 치료를 받은 여자 환자들에 서 증가하지 않았다는 보고도 있다. ${ }^{218,219)}$ 한 대규모 후향적 연구에서는 유산율의 증가 때문에 임신은 치료 후 1 년 뒤로 연기하여야 한다고 하였다. ${ }^{20)}$

남자에 있어서 방사성요오드 치료는 일시적인 정자 수의 감소와 FSH 수치의 증가와 연관이 있다. ${ }^{221,222)}$ 영구적인 남 성 불임은 단일 방사성요오드 치료와는 무관하며 이론적으 로 여러 번 시행으로 인한 손상이 누적되어 발생한다. 누적용 량이 $400 \mathrm{mCi}$ 이상인 남자 환자는 정자은행에 정자를 보관 할 것을 고려하여야 한다. ${ }^{223)}$ 생식선에 대한 방사선의 노출 을 줄이기 위해서는 방사성요오드 투여직후 수분의 공급과 방광을 비우기 위해 자주 소변을 보는 것이 좋고, 변비를 피 하는 것이 좋다. ${ }^{224)}$

- 방사성요오드 치료를 받는 여자는 치료 후 6 12개월 동 안 임신을 피해야 한다. 권고수준 3

- 방사성요오드는 수유 중인 산모에게는 투여해서는 안 된다.
임상적 상태에 따라 다르겠지만 방사성요오드 치료는 적어 도 6 8주 정도 수유를 중지한 후 하여야 한다. 권고수준 2 - 도파민성 약물이 최근 수유를 한 산모 유방의 방사선 노 출 감소에 도움이 될 수도 있으나, 통상적인 사용은 부작용 위험에 대해 충분한 검토와 주의가 필요하다. 권고수준 3

\section{혈청 $\mathrm{Tg}$ 양성 환자의 치료}

\section{경험적 방사성요오드 치료}

$\mathrm{TSH}-$ 억제 $\mathrm{Tg}$ 치가 양성이거나 $\mathrm{TSH}-$ 자극 $\mathrm{Tg}$ 치가 $2 \mathrm{ng} /$ $\mathrm{mL}$ 이상인 경우 두경부와 흥부의 전이 병소에 대한 검사가 권장되는데 대개 경부 초음파검사와 $5 \sim 7 \mathrm{~mm}$ 의 thin-cut helical 흥부CT가 적절하다. 그러나 수개월 내에 방사성 요 오드 치료가 예정되어 있으면 CT 검사시 요오드 조영제는 사 용하지 않도록 한다. 이전에 림프절 전이가 있던 환자는 초음 파 검사로 볼 수 없는 후두후방 림프절(retropharyngeal node)을 평가하기 위하여 횡단면의 CT나 MR시행도 고려한 다. 영상 검사 결과가 음성이거나, 혈청 $\mathrm{Tg}$ 수치가 수술로 제 거 가능해 보이는 병변에 비하여 높은 경우, 또는 $\mathrm{Tg}>10$ $\mathrm{ng} / \mathrm{mL}$ 이면 전신 F-18 FDG-PET을 시행할 수 있다. 수술 적으로 제거가 가능한 병소가 영상진단에서 발견되지 않으 면 1) 병소의 발견 또는 2) 수술적으로 제거가 불가능한 병 소에 대한 치료목적으로 100 200 mCi의 방사성요오드를 이용한 경험적 치료를 고려한다. 이러한 방법으로 약 $50 \%$ 에서 잔여 병소를 찾아낼 수 있었으며 일부에서는 치료의 효과가 보고되고 있다. ${ }^{188,225)}$ 일부에서는 혈청 $\mathrm{Tg}$ 농도가 경 험적 치료 후 감소 되었다는 보고가 있으나, ${ }^{226,227)}$ 아직까지 이러한 경우 생존율도 향상되었다는 증거는 없다. ${ }^{228,229)}$ 반 면에 일부에서는 특정 치료 없이도 혈청 $\mathrm{Tg}$ 의 수치가 감소 하기도 하였다. ${ }^{227)}$

혈청 $\mathrm{Tg}$ 농도가 어느 이상이 되면 경험적 방사성요오드 치 료를 하여야 하는지 결정하기는 어려운데 그 이유는 1) 매 우 다양한 $\mathrm{Tg}$ 측정법(경험적 치료가 도움이 된다는 보고에 서 사용된 측정법을 포함하여)이 있으며 2) $\mathrm{Tg}$ 수치는 측정 법과 TSH 자극 정도에 따라서 달라지기 때문이다. 최근의 보고에서는 주로 $\mathrm{LT}_{4}$ 중단 후 $\mathrm{Tg}$ 수치가 $10 \mathrm{ng} / \mathrm{mL}$ 이상이 거나 이에 상응하는 $\mathrm{rhTSH}$ 로 자극하였을 때 $5 \mathrm{ng} / \mathrm{mL}$ 이 상인 경우를 주로 치료 대상으로 삼았다. $186,225,227,229,230)$ 또 한 $\mathrm{Tg}$ 수치가 지속적으로 상승 추세를 보이는 경우에도 치 료를 고려하여야 하나 치료를 고려하여야 하는 변화의 정도 에 대하여서는 아직 결정된 바가 없다. ${ }^{184)}$ 
- 다른 영상 진단법으로 종양을 찾지 못하였으나 혈청 $\mathrm{Tg}$ 의 수치가 상승 $(\mathrm{Tg}$ 수치가 $\mathrm{T} 4$ 중단 후 $10 \mathrm{ng} / \mathrm{mL}$ 이상, 또는 $\mathrm{rhTSH}$ 자극 후 $5 \mathrm{ng} / \mathrm{mL}$ 이상) 하였거나 상승하는 양상인 경 우에 100 200 mCi의 방사성 요오드를 이용한 경험적 치료 를 고려할 수 있다. 권고수준 3

- 경험적 방사성요오드 치료 후에 수술적 제거가 불가능한 잔여종양이 발견되며 객관적으로 뚜렷한 종양의 감소가 관찰 되면, 종양이 사라지거나 종양이 더 이상 방사성요오드에 반 응하지 않을 때까지 방사성요오드 치료를 반복하여야 한다. 방사성요오드의 반복치료로 인한 위험성과 장기적으로 불확 실한 이익을 적절히 고려하여 균형을 맞추어야 한다. 권고수 준 3

- 구조적으로 분명한 병변이 없는 경우, 갑상선호르몬 중단 후 혈청 $\mathrm{Tg}<10 \mathrm{ng} / \mathrm{mL}$ 또는 $\mathrm{rhTSH}$ 자극 후 $<5 \mathrm{ng} / \mathrm{mL}$ 이면 시간 경과에 따라 혈청 $\mathrm{Tg}$ 가 상승하거나 다른 구조적인 병변 이 진행하는 것이 분명해질 때까지 추가적인 치료는 보류하 고, LT4 치료만 지속하면서 추적 관찰할 수 있다. 권고수준 3

혈청 $\mathrm{Tg}$ 양성이며 경험적 방사성요오드 치료 후 전신 스캔 음성인 환자

- 100 200 mCi의 방사성요오드를 이용한 경험적 치료 후 촬영한 전신스캔에서 잔여 병소가 발견되지 않으면 FDG$\mathrm{PET}$ 촬영을 고려하는데, 특히 TSH-억제 Tg의 수치가 10 $20 \mathrm{ng} / \mathrm{mL}$ 이상으로 높거나 공격적인 조직형의 암인 경우에 시행한다. ${ }^{231,232)}$ 권고수준 2

$\mathrm{LT}_{4}$ 중단을 이용한 내인성 $\mathrm{TSH}$ 나 $\mathrm{rhTSH}$ 를 이용한 자극 및 CT 융합 영상을 이용하여 $\mathrm{FDG}-\mathrm{PET}$ 스캔의 예민도와 특이도를 약간 높일 수 있다.

- 방사성요오드 전신 스캔 음성이나 혈청 $\mathrm{Tg}$ 양성이며, 수 술로 제거가 불가능하나 FDG-PET 사진에서 구조적으로 뚜 렷하게 보이는 전이 병소는 갑상선호르몬 억제치료, 외부 방 사선치료, 항암약물치료, 고주파 절제, 항암제 색전술 등으로 치료할 수 있으며 질환이 안정적인 경우에는 경과관찰만을 할 수도 있다. 또한 상기의 경우에는 진행 중인 임상시험에의 참여를 고려할 수 있다. 권고수준 3

- 방사성요오드 전신 스캔 음성이나 혈청 $\mathrm{Tg}$ 양성이며, 구 조적으로 뚜렷하게 보이는 전이병소가 없는 경우, 주기적인 영상검사와 혈청 $\mathrm{Tg}$ 측정으로 경과관찰을 한다. 만약 $\mathrm{Tg}$ 수
치가 증가하는 경우 검사간격을 줄이는 것이 좋다. 이 경우 DG-PET를 언제 실시하며 얼마나 자주 실시하는 것이 좋은 지는 아직 명확치 않다. 권고수준 3

\section{전이 병소에 대한 외부 방사선치료의 역할}

- 외부 방사선조사는 수술적 제거가 불가능한 경부 잔여 종 양, 통증을 동반한 골전이, 그리고 골절, 신경학적 이상, 또는 압박증상을 유발할 수 있는 중요 부위에 전이가 있고 수술적 제거가 어려운 경우(예: 척추전이, 중추신경계전이, 일부 종격 동 또는 subcarinal 림프절전이, 골반전이)에 고려된다. ${ }^{172,233)}$ 권고수준 2

\section{전이병소에 대한 항암화학요법의 역할}

방사성요오드치료에 반응이 없는 진행된 갑상선분화암에 대한 항암화학 요법에 대한 연구는 제한적이다. 적절한 용량 의 doxorubicin(3주 간격의 $60 \sim 75 \mathrm{mg} / \mathrm{m}^{2}$ ) 단독치료는 $40 \%$ 의 환자에게 효과가 있을 수 있다. ${ }^{234-236)}$ 그러나 대부분 부 분 관해 또는 안정 병변(stable disease) 정도의 반응이며 효과의 지속 여부는 불확실하다. 대부분의 복합 항암화학요 법은 doxorubicin 단독치료에 비하여 효과가 더 뛰어나다는 증거는 없고 독성만 증가하는 것으로 보고되었다. ${ }^{237)}$ 일부 전문가 들은 역형성 갑상선암에서의 제한적인 결과들을 바 탕으로 doxorubicin이나 paclitaxel 각각의 단독치료나 이 둘의 복합치료를 추천하기도 한다. ${ }^{238)}$ 최근에 갑상선호르몬 투여 중단이나 rhTSH 주사로 TSH를 자극한 후 carboplatinum과 epirubicin의 복합 치료에 대한 보고가 있었 는데 완전 및 부분 관해가 $37 \%$ 에서 관찰되었다. 하지만 아 직 일반적으로 사용을 고려하기 전에 재검증이 필요한 상황 이다. ${ }^{239)}$

임상시험이 진행 중이거나 연구개발 중인 새로운 약제로 는, 갑상선 암세포의 증식과 연관된 신호전달경로를 차단하 는 RET, RAS, RAF, MEK kinases 등의 억제제, 갑상선 암세포의 고사를 유도하고 성장을 억제하는 PPARy activators, COX2 inhibitors, rexinoids, bortezomib, geldanomycin 유도체 등이 있으며, 이외에도 VEGF 억제제, 면 역조절제(immune-modulators), 유전자 치료법 등에 대한 연구가 진행중이다.

- 항암화학요법은 방사성요오드 치료에 반응이 없는 진행성 갑상선암의 경우에 중등도의 효과를 지닌다. 진행성 갑상선 
암 환자의 경우 임상시험의 참여를 고려하여야 한다. 만약 임 상시험이 적용되기 어려운 상황이거나 환자가 표준적인 항암 화학요법을 원하는 경우 doxorubicin을 단독으로 사용하거나 doxorubicin과 다른 약물과의 병합치료를 고려할 수 있다. 권고수준 3

\section{갑상선수질암}

\section{자연사 및 병인}

갑상선수질암은 칼시토닌을 분비하는 갑상선 여포곁세포 혹은 C 세포에서 기원하는 종양인데, $80 \%$ 는 산발성으로, 나 머지 20\%는 MEN 2A, MEN2B 또는 가족성 갑상선수질암 같은 유전성 암 증후군의 일원으로 발생한다.

산발성 갑상선수질암은 특징적으로 40 50대에 발현되며 여성이 약간 많다. 진단시 약 $50 \%$ 의 환자에서 경부 림프절전 이가 발견되며 약 $15 \%$ 에서 상부위장관 압박 또는 침범 증상 이 동반되고, ${ }^{240)} 5 \sim 10 \%$ 에서는 폐나 뼈로의 원격전이가 나타 나는 것으로 보고되어 있어 갑상선분화암에 비해 예후가 나 쁘다. 칼시토닌 외에 도 호르몬 기능이 있는 펩티드(ACTH나 calcitonin-gene related peptide)를 종종 분비하여 환자 에게 설사, 쿠싱 증후군, 안면 홍조 등을 일으킬 수 있다.

가족성 갑상선수질암은 대개 20 대에 발현이 되고 성별에 따른 빈도의 차이는 없다. 가족성 갑상선수질암의 경우 갈색 세포종이나 부갑상선기능 항진증이 동시에 혹은 이후에 발 현이 될 가능성이 있다는 것을 항상 고려하여야 한다. ${ }^{241)}$

\section{진단과 병기판정}

산발성 갑상선수질암은 보통 단독 결절의 $\mathrm{FNAC}$ 에서 보이 는 특징적인 세포 모양이나 칼시토닌에 대한 면역화학염색 또는 혈청 칼시토닌의 상승으로 의심할 수 있다. 그러나, 갑 상선결절 환자에서 갑상선수질암을 선별하기 위해 일상적으 로 칼시토닌을 측정할 것인가에 대해서는 논란의 여지가 있 다. 일부에서는 비용 때문에 혈청 칼시토닌 농도의 일상측정 을 권고하지 않는 반면, ${ }^{26,242-244)}$ 산발성 갑상선수질암의 진 단을 위해서는 혈청 칼시토닌 농도의 측정이 비용대비 효과 적 이므로 갑상선수질암 진단의 민감도를 높이기 위한 중요 한 검사로 권고되는 경우 도 있다. ${ }^{26,243,245)}$ 또한, 수술 전 칼시 토닌의 상승정도는 암의 크기, 림프절과 원격전이 여부와 수 술 후 칼시토닌 정상화와 관련되어 있다는 주장도 있다. ${ }^{246)}$

갑상선수질암 환자를 수술하기 전에 혈청 종양 표지자검 사(칼시토닌과 $\mathrm{CEA}$ )와 유전성암증후군을 배제하기 위한 검 사, 즉, 갈색세포종 $(\mathrm{MEN} 2 \mathrm{~A}$ 및 $2 \mathrm{~B})$ 과 부갑 상선기능항진증
(MEN 2A)에 대한 생화학적 선별검사 및 생식세포(germline) $\mathrm{RET}$ 원발암유전자(protooncogene) 돌연변이 선별검사 등 을 시행하여야 한다. 또한, 성대의 운동성도 반드시 확인해야 한다. 국소 림프절전이를 확인하기 위해 서 경부 초음파검사 를 시행하여야 하나 유전자 선별검사로 진단된 젊은 환자에 서는 림프절전이의 빈도가 매우 낮기 때문에 초음파를 권고 하지는 않는다.

- 수술 전 검사에는 혈청 표지자(칼시토닌, CEA) 측정과 갈색 세포종(MEN 2A \& 2B)과 부갑상선기능항진증을 진단하기 위 한 생화학적 선별검사 및 RET 원발암 유전자 돌연변이 선별 검사 등이 포함된다. 권고수준 2

- 성대 운동성을 확인할 필요가 있다. 권고수준 3

- 유전성 갑상선갑상선수질암 환자의 친족뿐만 아니라, 임상 적으로 산발성으로 생각되는 갑상선수질암으로 새로 진단받 은 모든 사람에게 RET 원발암 유전자 돌연변이에 대한 선별 검사를 고려해야 된다. 변이의 상대적 빈도에 근거하여 엑손 11 에서 시작하여 순차적으로 엑손 $10,16,13,14,15$ 번에 대한 변이 분석을 시행한다. 권고수준 2

병기 결정: $\mathrm{AJCC}(7$ 판)의 TNM 체계(Table 3)에 의거해 암의 크기, 갑상선외 침범의 유무, 국부의 림프절전이와 원 격전이 유무에 따라 병기를 결정한다. ${ }^{247}$ 갑상선을 벗어나지 않는 $2 \mathrm{~cm}$ 이하의 갑상선수질암은 I기(T1NOMO), 림프절 및 원격전이가 없는 갑상선에 국한된 $2 \mathrm{~cm}$ 보다 크고 $4 \mathrm{~cm}$ 이하 의 병변은 II기(T2-T3NOM0)로 분류한다. Level VI 림프절 전이가 있고 현미경적 갑상선외 침윤이 있는 경우는 III기 (T1-T3N1aM0)에 해당하고, 갑상선 주변 연부조직까지 육 안적 침범이 있거나 level VI를 벗어난 림프절전이가 있거나 원격전이가 있는 경우는 IV기로 분류한다(Table 5).

\section{수술방법과 시기}

명백하게 산발성 갑상선수질암으로 생각되는 환자라도 수술 전에 부갑상선 기능항진증과 갈색세포종에 대한 생화 학적 선별검사 및 $\mathrm{RET}$ 원발암유전자 변이 검사로 $\mathrm{MEN} 2$

Table 5. TNM classification system for medullary thyroid carcinoma

\begin{tabular}{llll}
\hline Stage I & T1 & NO & MO \\
Stage II & T2, T3 & NO & MO \\
Stage III & T1-T3 & Nla & MO \\
Stage IVA & T4a & NO, N1a & MO \\
& T1-T4a & N1b & MO \\
Stage IVB & T4b & Any N & MO \\
Stage IVC & Any T & Any N & M \\
\hline
\end{tabular}


의 가능성을 반드시 배제해야만 한다. 갑상선수질암은 양 측성 질환의 가능성이 높기 때문에 모든 환자에서 갑상선전 절제술을 시행하는 것을 권고한다. ${ }^{240)}$

유전성 질환을 가진 환자는 5 세까지는 갑상선전절제술을 받도록 권고하고 있으나, 코돈 883, 918, 922번 RET 변이 가 있는 $\mathrm{MEN} 2 \mathrm{~B}$ 환자는 1 세까지 또는 진단 시 갑상선전절 제술을 시행하여야 한다. 반면 코돈 768, 790, 791, 804번 $\mathrm{RET}$ 변이가 있는 경우에는 다른 RET 변이에 비해 갑상선 수질암의 치명률이 낮으므로 칼슘 유발 칼시토닌 검사가 비 정상화되는 때까지 수술을 연기할 수 있다. ${ }^{248)}$ 또한, 코돈 $768,790,791$ 번 RET 유전자 변이를 가진 소아에서는 갑상 선수질암의 발현 시점이 늦기 때문에 10 세까지 갑상선전절 제술을 연기할 수도 있다. ${ }^{241)}$

양측 중앙 림프절(level VI) 절제술은 조직학적으로 증명 된 모든 갑상선 수질암 환자 및 $\mathrm{MEN} 2 \mathrm{~B}$ 환자에게 권고되 며, 예방적 갑상선전절제술을 시행하는 $\mathrm{MEN} 2 \mathrm{~A}$ 환자에서 는 칼슘자극 칼시토닌 검사에 이상이 있거나 초음파상 갑상 선 또는 림프절 이상을 보이는 환자에서 고려할 수 있다. 갑 상선수질암과 부갑상선기능 항진증이 동시에 진단된 $\mathrm{MEN}$ $2 \mathrm{~A}$ 환자에서 다발성 부갑상선증식증이 있는 경우 한 개의 부갑상선을 자가이식하거나, 절제된 부갑상선조직을 냉동보 존하여 의인 성 부갑상선기능저하증이 있을 때 이식할 수 있도록 준비한다.

수술 후 갑상선호르몬 보충치료는 필요하나 C 세포는 갑 상선자극호르몬 수용체가 없기 때문에 갑상선자극호르몬 억제는 권고되지 않는다.

\section{예방적 수술}

- MEN 2B 환자는 1세 이전에 가능하면 빨리 예방적 갑상선 전절제술을 하도록 권고하며 이 때 임상적으로 림프절 전이가 없고 갑상선 결절이 $5 \mathrm{~mm}$ 이하이며 혈중 기저 칼시토닌이 40 $\mathrm{pg} / \mathrm{mL}$ 이하이면 예방적 중앙 림프절절제술은 생략할 수 있 다. 권고수준 3

- 코돈 $634 \mathrm{RET}$ 변이를 가진 환자는 5세 이전에 예방적 갑 상선전절제술을 하도록 권고한다. 권고수준 1

- 3 5세에 예방적 갑상선전절제술을 받는 MEN 2A 또는 가 족성 수질암 환자는 임상적으로 림프절 전이가 없고 갑상선 결절이 $5 \mathrm{~mm}$ 이하이며 혈중 기저칼시토닌이 $40 \mathrm{pg} / \mathrm{mL}$ 이하 이면 예방적 중앙 림프절절제술이 필요하지 않다. 권고수준 2 - 소아기에 시행하는 예방적 갑상선전절제술은 부갑상선 및 반회후두신경 기능 보존에 우선 순위를 두어야 하며 경험이 많은 술자에 의해 시행하도록 권고한다. 권고수준 3

\section{치료적 수술}

- 진행된 국소침윤이 없고 진찰이나 초음파상 림프절 전이가 없으며 원격전이가 없는 수질암 환자에서는 갑상선 전절제술 과 중앙 림프절 절제술을 하도록 권고 한다. 권고수준 2

- 중앙 림프절에만 전이가 있거나 제한적인 원격전이가 있는 수질암 환자에서는 대개 갑상선 전절제술과 중앙 림프절 절제 술을 시행하나, 인접한 기관주위 림프절에 전이가 있을 경우 예방적 측경부 림프절절제술을 고려할 수 있다. 권고수준 2

- 중앙 및 측경부 림프절에 전이가 있으면서 원격전이가 없거 나 제한적인 수질암 환자에서는 갑상선 전절제술과 중앙(level VI) 및 측경부(level IIA, III, IV, V) 림프절절제술을 하도록 권고 한다. 권고수준 2

\section{국소진행암 또는 원격전이 시 수술}

- 진행된 국소병변이나 원격전이가 있다면 국소 및 경부 병변 을 제거하되 언어, 연하 및 부갑상선 기능을 보존하기 위해 덜 공격적인 수술이 적절할 수 있다. 권고수준 3

- 광범위한 원격전이가 있더라도 통증을 완화하거나 기도를 확보할 목적으로 고식적 경부수술이 필요할 수 있다. 권고수 준 3

\section{보조적 방사선 치료의 역할}

갑상선수질암에서 주위조직으로 침범이 있거나 광범위한 국소림프절전이가 있는 경우 외부 방사선조사 치료로 무병 생존율을 약간 증가시켰다는 보고가 있으나 아직 체계적으 로 연구된 적은 없다. 그러나 $\mathrm{T} 4 \mathrm{a}$ 병변을 가진 환자 또는 분화암에서의 경우와 마찬가지로 통증이 있거나 진행하는 골전이를 경감시키기 위해 시행할 수 있다.

- 통증이 있거나 진행하는 골전이를 경감시키기 위해서 보 조적 방사선 치료를 시행할 수 있다. 권고수준 2

\section{수술 후 잔존암의 평가 및 추적관찰}

수술 후 잔존암의 평가를 위한 기본 검사는 수술 2 3개 월 후 혈청 칼시토닌 과 $\mathrm{CEA}$ 농도를 측정하는 것이다. 칼시 토닌 기저치가 측정한계 미만이면 칼슘에 의한 자극검사를 고려할 수 있으나, ${ }^{249)}$ 기저치는 정상이고 칼슘자극 칼시토닌 치만 증가되어 있는 경우의 임상적 의미는 아직 불확실하다. 자극 후에도 칼시토닌 농도가 측정되지 않는다면 매년 혈청 표지자 측정 및 정기적인 영상학적 진단을 시행하고 추가로 칼시토닌 자극 검사를 고려할 수 있다. 
$\mathrm{MEN} 2 \mathrm{~A}, 2 \mathrm{~B}$ 의 경우에는 매년 갈색세포종이나 부갑상선 기능항진증에 대한 선별검사를 시행하여야 하지만, 일부 RET 변이(즉, 코돈768, 790, V804M, 891번)의 경우에는 자주 하 지 않아도 된다. 혈청 표지자의 기저치가 증가되어 있는 경우 에는 잔존 또는 전이병변의 위치를 확인하기 위한 영상진단 법이 필요하지만, 특별하게 권고할 만한 충분한 증거가 있 는 것은 없다. 잔존 또는 전이 병변의 위치 확인에 실패하였 을 경우 매년 혈청 종양 표지자 측정 및 상부 종격동, 양측 중심구획 그리고 양측 경부를 확인하는 고해상도 경부초음 파를 포함하는 영상 검사를 반복 시행한다. 기저 칼시토닌 농 도가 $1,000 \mathrm{pg} / \mathrm{mL}$ 이상이고 경부 및 상부 종격동에 이상이 없는 경우에는 원격전이의 가능성을 고려하여야 하는데, 간 에 전이되는 경우가 가장 흔하다. 혈청 종양 표지자가 증가 하는 환자는 더 자주 영상학적 검사를 시행하여야 하며, 임 상연구 외에는 비정상적인 표지자만으로 치료적 중재를 권 고하지는 않는다.

- 수술 후 잔존암의 평가를 위해 혈청 칼시토닌과 CEA 농 도를 측정한다. 권고수준 2

- 혈청 칼시토닌 농도가 높은 경우 경부에 잔존하는 절제가 능한 병변이나 원격전이의 존재를 찾기 위한 검사를 시행하 여야 한다. 권고수준 3

\section{재발 또는 잔존 병변에 대한 치료}

원격전이 없이 국소 재발이 확인된 경우 수술적 제거가 원칙이나 수술이 불가능하다면 방사선 치료를 시행한다. 원 격전이가 있는 경우 국소 질환은 제거를 하거나, 선택적으 로 방사선치료를 고려하며, 증상을 일으키는 원격전이는 수 술적 제거, 방사선 치료, 고주파치료, 화학색전치료 또는 다 른 국소치료를 고려해 볼 수 있다. 이러한 치료는 증상이 없 는 원격전이를 가진 환자에게도 적용할 수 있으나, 보존적 인 관찰도 용인될 수 있다.

- 원격전이 없이 국소 재발이 확인된 경우 수술적 제거가 권 고된다. 만약 수술이 불가능하다면 방사선 치료가 권고된다. 권고수준 3

\section{갑상선역형성암(미분화암)}

\section{자연사 및 병인}

갑상선역형성암은 가장 공격적인 미분화암으로 질병 특이 사망률이 $100 \%$ 에 이른다. 진단 시 평균연령은 약 65 세로 갑
상선분화암에 비해 높고, $10 \%$ 미만의 환자에서만 50 세 이 전에 발생하며 환자의 60 70\%가 여성이다. ${ }^{250)}$ 약 $50 \%$ 의 환 자는 선행 또는 공존하는 갑상선분화암을 가지고 있으며, p53 종양 억제 유전자의 소실과 같은 하나 또는 그 이상의 탈분 화 과정을 거쳐 분화암으로부터 발생 한다고 알려져 있으 나, 역형성 변이를 유발하는 기전이나 악화인자는 밝혀져 있 지 않은 상태이다. ${ }^{251,252)}$

갑상선역형성암 환자의 15 50\%는 진단 시 이미 광범위한 주위조직 침윤이나 원격전이를 동반하는데, 원격전이의 $90 \%$ 는 폐와 흥막 전이이며, $5 \sim 15 \%$ 는 골전이, $5 \%$ 는 뇌전이를 동 반한다. ${ }^{253,254)}$ 드물게 피부, 간, 신장, 췌장, 심장과 부신에 전 이되기도 한다. ${ }^{255)}$

\section{진단과 병기판정}

모든 갑상선역형성암은 $\mathrm{T} 4$ 종양으로 간주되며 병기는 IV 기(A, B, C; Table 6)로 분류된다. T4a는 종양이 갑상선 내에 국한되어 수술적 제거가 가능한 경우, T4b는 갑상선 밖으로 종양이 퍼지고 수술적 제거가 불가능한 경우이다.

갑상선역형성암은 $\mathrm{FNAC}$ 또는 조직 생검으로 수술 전에 확진할 수 있다. 갑상선 주변의 주요 구조물(혈관, 기도, 식도 등)의 침범 정도는 경부 및 종격동의 전산화단층촬영으로 확 인할 수 있고, 폐로의 원격전이는 대개 폐결절의 형태로 나 타나므로 흥부 X선촬영으로 진단이 가능하다. 골전이는 대 부분 골용해의 형태로 나타난다.

- 갑상선 종양의 정확한 범위와 주요 혈관, 상기도 또는 상 부위장관의 침범여부를 확인하기 위하여 경부 및 종격동의 전산화단층촬영이 필요하다. ${ }^{256)}$ 권고수준 2

\section{치 료}

갑상선역형성암에 대한 효과적인 치료법은 없다. 때문에 모든 환자가 결국 사망에 이르게 된다. 진단 시점으로부터 중 앙 생존기간이 3 7개월이고, 1 년, 5 년 생존율이 각각 $25 \%$ 와 $5 \%$ 이다. 환자의 $50 \%$ 가 상기도 폐쇄로 인한 질식으로, 나머 지 환자들은 국소 또는 전이 병소나 치료의 합병증으로 사망 한다. 진단 시 종양이 경부에 국한되어 있는 경우 평균생존기 간이 8개월이며 그렇지 않은 경우는 3 개월이다. ${ }^{257)}$ 나쁜 예후 인자들은 고령, 남성, 주 증상이 호흡곤란인 경우이다. ${ }^{254,258)}$

Table 6. TNM classification system for anaplastic thyroid carcinoma

\begin{tabular}{lcll}
\hline Stage IVA & T4a & Any N & M0 \\
Stage IVB & T4b & Any N & M0 \\
Stage IVC & Any T & Any N & M1 \\
\hline
\end{tabular}


종양이 크기가 작고 갑상선에만 국한되어 있어 쉽게 제거 가능한 경우를 제외하고는 종양 전적출술을 포함한 갑상선 전절제술이 생존을 증가시키지 못한다. ${ }^{257,259,260)}$ 마찬가지로, 통상적 용량의 방사선치료도 생존을 증가시키지 못한다. 환 자의 $40 \%$ 정도가 초기에는 방사선치료에 반응이 있으나 대 부분 국소재발을 한다. 단일항암약물치료도 원격전이가 있 는 환자의 $20 \%$ 에서 반응을 유도하나 질병을 조절하거나 생 존을 증가시키지 못한다. 방사선 민감제로 doxorubicin을 투여하면서 동시에 시행하는 과다분할 방사선치료가 국소 반응률을 $80 \%$ 정도까지 증가시키며 중앙생존기간을 1년으 로 증가시킨다는 보고가 있다. ${ }^{261)}$ 그러나 고용량의 다른 항 암제를 추가한 병합치료가 원격전이를 조절하거나 생존율 을 증가시켰다는 보고는 없다. Paclitaxel이 새로 진단된 환 자에게 사용되고 있으며 일부 고식적인 치료효과가 있을 것 으로 보인다. ${ }^{262)}$ 일단 조직학적으로 갑상선 역형성암으로 진 단이 되면 전체 환자의 $50 \%$ 가 경부에서 발생한 제어할 수 없는 병변으로 사망하므로 국소 절제의 가능성을 판정해야 한다. ${ }^{260}$

- 경부 전산화단층촬영과 흉부 $X$ 선 검사를 시행하여 절제 가능성이 있는 것으로 보이면 갑상선전절제술 또는 아전절제 술을 시행하여야 한다. 완전 절제가 불가능한 종양을 가진 환 자의 경우에는 예방적 기관절개술을 포함하여 기도를 보호하 는 것이 우선이다. 권고수준 2

- 수술의 시행여부와 상관없이 모든 환자는 복합치료를 받 아야 한다. 비록 항암제와 병용하여 시행한 과다분할방사선 치료가 일부 효과를 보였지만 심각한 독성이 관찰되었으며 지속적인 관해를 이루기도 어렵다. 현재까지 특정 치료가 효 과적이라는 근거가 없으므로 특정한 항암제 사용은 권고를 보류한다. 따라서 방사선 치료나 화학 치료 외에 임상시험 단 계의 다른 치료방법도 고려의 대상이 된다. 권고수준 2

\section{Acknowledgments}

This guideline was established by Korean Thyroid Association in coordination with Korean Endocrine Society, The Korean Society of Pathologists, The Korean Society of Radiology, Korean Association of Thyrid and Endocrine Surgeons, The Korean Society of Head and Neck Surgery, and The Korean Society of Nuclear Medicine.

\section{REFERENCES}

1) Kim WB, Kim TY, Kwon HS, Moon WJ, Lee JB, Choi YS, et al. Management Guidelines for Patients with Thyroid Nodules and Thyroid Cancer. J Korean Endocr Soc 2007;22:157-87.

2) Cooper DS, Doherty GM, Haugen BR, Kloos RT, Lee SL, Mandel SJ, et al. Management guidelines for patients with thyroid nodules and differentiated thyroid cancer. Thyroid 2006;16(2):109-42.

3) American Thyroid Association (ATA) Guidelines Taskforce on
Thyroid Nodules and Differentiated Thyroid Cancer, Cooper DS, Doherty GM, Haugen BR, Kloos RT, Lee SL, et al. Revised American Thyroid Association management guidelines for patients with thyroid nodules and differentiated thyroid cancer. Thyroid 2009;19(11):1167-214.

4) Gharib H, Papini E, Paschke R, Duick DS, Valcavi R, Hegedüs L, et al. American Association of Clinical Endocrinologists, Associazione Medici Endocrinologi, and EuropeanThyroid Association Medical Guidelines for Clinical Practice for the Diagnosis and Management of Thyroid Nodules. Endocr Pract 2010;16 Suppl 1: 1-43.

5) Ali SZ, Cibas ES. The Bethesdasystem for reporting thyroid cytopathology. New York: Springer;2010.

6) Marqusee E, Benson CB, Frates MC, Doubilet PM, Larsen PR, Cibas ES, et al. Usefulness of ultrasonography in the management of nodular thyroid disease. Ann Intern Med 2000;133(9):696-700.

7) Hagag P, Strauss S, Weiss M. Role of ultrasound-guided fine-needle aspiration biopsy in evaluation of nonpalpable thyroid nodules. Thyroid 1998;8(11):989-95.

8) Moon WJ, Jung SL, Lee JH, Na DG, Baek JH, Lee YH, et al. Benign and malignant thyroid nodules: US differentiation--multicenter retrospective study. Radiology 2008;247(3):762-70.

9) Bonavita JA, Mayo J, Babb J, Bennett G, Oweity T, Macari M, et al. Pattern recognition of benign nodules at ultrasound of the thyroid: which nodules can be left alone? AJR Am J Roentgenol 2009;193 (1):207-13.

10) Moon WJ, Kwag HJ, Na DG. Are there any specific ultrasound findings of nodular hyperplasia ("leave me alone" lesion) to differentiate it from follicular adenoma? Acta Radiol 2009;50(4):383-8.

11) Frates MC, Benson CB, Charboneau JW, Cibas ES, Clark OH, Coleman BG, et al. Management of thyroid nodules detected at US: Society of Radiologists in Ultrasound consensus conference statement. Radiology 2005;237(3):794-800.

12) Papini E, Guglielmi R, Bianchini A, Crescenzi A, Taccogna S, Nardi F, et al. Risk of malignancy in nonpalpable thyroid nodules: predictive value of ultrasound and color-Doppler features. J Clin Endocrinol Metab 2002;87(5):1941-6.

13) Wienke JR, Chong WK, Fielding JR, Zou KH, Mittelstaedt CA. Sonographic features of benign thyroid nodules: interobserver reliability and overlap with malignancy. J Ultrasound Med 2003;22(10): 1027-31.

14) Kim EK, Park CS, Chung WY, Oh KK, Kim DI, Lee JT, et al. New sonographic criteria for recommending fine-needle aspiration biopsy of nonpalpable solid nodules of the thyroid. AJR Am J Roentgenol 2002;178(3):687-91.

15) Moon WJ, Lee JH, Jung SL, Na DG, Baek JH, Lee YH, et al. U1trasonographic findings of benign and malignant thyroid nodules: A multicenter retrospective study. Ultrasound Med Biol 2006; 32;5S:120.

16) Camargo R, Corigliano S, Friguglietti C, Gauna A, Harach R, Munizaga $\mathrm{F}$, et al. Latin American thyroid society recommendations for the management of thyroid nodules. Arq Bras Endocrinol Metabol 2009;53(9):1167-75.

17) Curtis RE, Rowlings PA, Deeg HJ, Shriner DA, Socíe G, Travis LB, et al. Solid cancers after bone marrow transplantation. N Engl J Med 1997;336(13):897-904.

18) Pacini F, Vorontsova T, Demidchik EP, Molinaro E, Agate L, Romei $\mathrm{C}$, et al. Post-Chernobyl thyroid carcinoma in Belarus children and adolescents: comparison with naturally occurring thyroid carcinoma in Italy and France. J Clin Endocrinol Metab 1997;82(11): 3563-9.

19) Hall TL, Layfield LJ, Philippe A, Rosenthal DL. Sources of diagnostic error in fine needle aspiration of the thyroid. Cancer 1989;63(4): $718-25$. 
20) Brander A, Viikinkoski P, Tuuhea J, Voutilainen L, Kivisaari L. Clinical versus ultrasound examination of the thyroid gland in common clinical practice. J Clin Ultrasound 1992;20(1):37-42.

21) Tan GH, Gharib H, Reading CC. Solitary thyroid nodule. Comparison between palpation and ultrasonography. Arch Intern Med 1995; 155(22):2418-23.

22) Singh B, Shaha AR, Trivedi H, Carew JF, Poluri A, Shah JP. Coexistent Hashimoto's thyroiditis with papillary thyroid carcinoma: impact on presentation, management, and outcome. Surgery 1999; 126(6):1070-6; discussion 1076-7.

23) Repplinger D, Bargren A, Zhang YW, Adler JT, Haymart M, Chen H. Is Hashimoto's thyroiditis a risk factor for papillary thyroid cancer? J Surg Res 2008;150(1):49-52.

24) Pacini F, Pinchera A, Giani C, Grasso L, Doveri F, Baschieri L. Serum thyroglobulin in thyroid carcinoma and other thyroid disorders. J Endocrinol Invest 1980;3(3):283-92.

25) Hahm JR, Lee MS, Min YK, Lee MK, Kim KW, Nam SJ, et al. Routine measurement of serum calcitonin is useful for early detection of medullary thyroid carcinoma in patients with nodular thyroid diseases. Thyroid 2001;11(1):73-80.

26) Niccoli P, Wion-Barbot N, Caron P, Henry JF, de Micco C, Saint Andre JP, et al. Interest of routine measurement of serum calcitonin: study in a large series of thyroidectomized patients. The French Medullary Study Group. J Clin Endocrinol Metab 1997;82(2):33841.

27) Elisei R, Bottici V, Luchetti F, Di Coscio G, Romei C, Grasso L, et al. Impact of routine measurement of serum calcitonin on the diagnosis and outcome of medullary thyroid cancer: experience in 10,864 patients with nodular thyroid disorders. J Clin Endocrinol Metab 2004;89(1):163-8.

28) Gagel RF, Hoff AO, Cote GJ. Medullary thyroid carcinoma. In Werner and Ingbar's The Thyroid: A Fundamental and Clinical Text. Philadelphia: Lippincott Williams and Wilkins;2005. p.967-88.

29) Mandel SJ. A 64-year-old woman with a thyroid nodule. JAMA 2004;292(21):2632-42.

30) Braga M, Cavalcanti TC, Collaço LM, Graf H. Efficacy of ultrasound-guided fine-needle aspiration biopsy in the diagnosis of complex thyroid nodules. J Clin Endocrinol Metab 2001;86(9):4089-91.

31) de los Santos ET, Keyhani-Rofagha S, Cunningham JJ, Mazzaferri EL. Cystic thyroid nodules. The dilemma of malignant lesions. Arch Intern Med 1990;150(7):1422-7.

32) Yeh MW, Demircan O, Ituarte P, Clark OH. False-negative fineneedle aspiration cytology results delay treatment and adversely affect outcome in patients with thyroid carcinoma. Thyroid 2004;14 (3):207-15.

33) Yassa L, Cibas ES, Benson CB, Frates MC, Doubilet PM, Gawande $\mathrm{AA}$, et al. Long-term assessment of a multidisciplinary approach to thyroid nodule diagnostic evaluation. Cancer 2007;111(6):508-16.

34) Layfield LJ, Abrams J, Cochand-Priollet B, Evans D, Gharib H, Greenspan F, et al. Post-thyroid FNA testing and treatment options: a synopsis of the National Cancer Institute Thyroid Fine Needle Aspiration State of the Science Conference. Diagn Cytopathol 2008; 36(6):442-8.

35) Tuttle RM, Lemar H, Burch HB. Clinical features associated with an increased risk of thyroid malignancy in patients with follicular neoplasia by fine-needle aspiration. Thyroid 1998;8(5):377-83 .

36) Kelman AS, Rathan A, Leibowitz J, Burstein DE, Haber RS. Thyroid cytology and the risk of malignancy in thyroid nodules: importance of nuclear atypia in indeterminate specimens. Thyroid 2001; 11(3):271-7.

37) Franco C, Martínez V, Allamand JP, Medina F, Glasinovic A, Osorio $\mathrm{M}$, et al. Molecular markers in thyroid fine-needle aspiration biopsy: a prospective study. Appl Immunohistochem Mol Morphol 2009;17(3):211-5.
38) Bartolazzi A, Orlandi F, Saggiorato E, Volante M, Arecco F, Rossetto R, et al. Galectin-3-expression analysis in the surgical selection of follicular thyroid nodules with indeterminate fine-needle aspiration cytology: a prospective multicentre study. Lancet Oncol 2008; 9(6):543-9.

39) Nikiforov YE, Steward DL, Robinson-Smith TM, Haugen BR, Klopper JP, Zhu Z, et al. Molecular testing for mutations in improving the fine-needle aspiration diagnosis of thyroid nodules. J Clin Endocrinol Metab 2009;94(6):2092-8.

40) Tyler DS, Winchester DJ, Caraway NP, Hickey RC, Evans DB. Indeterminate fine-needle aspiration biopsy of the thyroid: identification of subgroups at high risk for invasive carcinoma. Surgery 1994; 116(6):1054-60

41) Gharib H, Goellner JR, Johnson DA. Fine-needle aspiration cytology of the thyroid. A 12-year experience with 11,000 biopsies. Clin Lab Med 1993;13(3):699-709.

42) Leenhardt L, Hejblum G, Franc B, Fediaevsky LD, Delbot T, Le Guillouzic D, et al. Indications and limits of ultrasound-guided cytology in the management of nonpalpable thyroid nodules. J Clin Endocrinol Metab 1999;84(1):24-8.

43) Carmeci C, Jeffrey RB, McDougall IR, Nowels KW, Weigel RJ. Ultrasound-guided fine-needle aspiration biopsy of thyroid masses. Thyroid 1998;8(4):283-9.

44) Ylagan LR, Farkas T, Dehner LP. Fine needle aspiration of the thyroid: a cytohistologic correlation and study of discrepant cases. Thyroid 2004;14(1):35-41.

45) Alexander EK, Hurwitz S, Heering JP, Benson CB, Frates MC, Doubilet PM, et al. Natural history of benign solid and cystic thyroid nodules. Ann Intern Med 2003;138(4):315-8.

46) Danese D, Sciacchitano S, Farsetti A, Andreoli M, Pontecorvi A. Diagnostic accuracy of conventional versus sonography-guided fineneedle aspiration biopsy of thyroid nodules. Thyroid 1998;8(1):15-21.

47) Erdoğan MF, Kamel N, Aras D, Akdoğan A, Başkal N, Erdoğan G. Value of re-aspirations in benign nodular thyroid disease. Thyroid 1998;8(12):1087-90.

48) Orlandi A, Puscar A, Capriata E, Fideleff H. Repeated fine-needle aspiration of the thyroid in benign nodular thyroid disease: critical evaluation of long-term follow-up. Thyroid 2005;15(3):274-8.

49) Papini E, Petrucci L, Guglielmi R, Panunzi C, Rinaldi R, Bacci V, et al. Long-term changes in nodular goiter: a 5 -year prospective randomized trial of levothyroxine suppressive therapy for benign cold thyroid nodules. J Clin Endocrinol Metab 1998;83(3):780-3.

50) Brander AE, Viikinkoski VP, Nickels JI, Kivisaari LM. Importance of thyroid abnormalities detected at US screening: a 5-year followup. Radiology 2000;215(3):801-6.

51) Zelmanovitz F, Genro S, Gross JL. Suppressive therapy with levothyroxine for solitary thyroid nodules: a double-blind controlled clinical study and cumulative meta-analyses. J Clin Endocrinol Metab 1998;83(11):3881-5.

52) Castro MR, Caraballo PJ, Morris JC. Effectiveness of thyroid hormone suppressive therapy in benign solitary thyroid nodules: a meta-analysis. J Clin Endocrinol Metab 2002;87(9):4154-9.

53) Wémeau JL, Caron P, Schvartz C, Schlienger JL, Orgiazzi J, Cousty $\mathrm{C}$, et al. Effects of thyroid-stimulating hormone suppression with levothyroxine in reducing the volume of solitary thyroid nodules and improving extranodular nonpalpable changes: a randomized, double-blind, placebo-controlled trial by the French Thyroid Research Group. J Clin Endocrinol Metab 2002;87(11):4928-34.

54) Rallison ML, Dobyns BM, Keating FR Jr, Rall JE, Tyler FH. Thyroid nodularity in children. JAMA 1975;233(10):1069-72.

55) Hung W. Solitary thyroid nodules in 93 children and adolescents. a 35-years experience. Horm Res 1999;52(1):15-8.

56) Raab SS, Silverman JF, Elsheikh TM, Thomas PA, Wakely PE. Pediatric thyroid nodules: disease demographics and clinical manage- 
ment as determined by fine needle aspiration biopsy. Pediatrics 1995; 95(1):46-9.

57) Corrias A, Einaudi S, Chiorboli E, Weber G, Crinò A, Andreo M, et al. Accuracy of fine needle aspiration biopsy of thyroid nodules in detecting malignancy in childhood: comparison with conventional clinical, laboratory, and imaging approaches. J Clin Endocrinol Metab 2001;86(10):4644-8.

58) Gharib H, Zimmerman D, Goellner JR, Bridley SM, LeBlanc SM. Fine-needle aspiration biopsy: use in diagnosis and management of pediatric thyroid diseases. Endocr Pract 1995;1(1):9-13.

59) Arda IS, Yildirim S, Demirhan B, Firat S. Fine needle aspiration biopsy of thyroid nodules. Arch Dis Child 2001;85(4):313-7.

60) Tan GH, Gharib H, Goellner JR, van Heerden JA, Bahn RS. Management of thyroid nodules in pregnancy. Arch Intern Med 1996;156 (20):2317-20.

61) Mestman JH, Goodwin TM, Montoro MM. Thyroid disorders of pregnancy. Endocrinol Metab Clin North Am 1995;24(1):41-71.

62) Herzon FS, Morris DM, Segal MN, Rauch G, Parnell T. Coexistent thyroid cancer and pregnancy. Arch Otolaryngol Head Neck Surg 1994;120(11):1191-3.

63) Moosa M, Mazzaferri EL. Outcome of differentiated thyroid cancer diagnosed in pregnant women. J Clin Endocrinol Metab 1997;82(9): 2862-6.

64) Mazzaferri EL, Jhiang SM. Long-term impact of initial surgical and medical therapy on papillary and follicular thyroid cancer. Am J Med 1994;97(5):418-28.

65) Hay ID, Bergstralh EJ, Goellner JR, Ebersold JR, Grant CS. Predicting outcome in papillary thyroid carcinoma: development of a reliable prognostic scoring system in a cohort of 1779 patients surgically treated at one institution during 1940 through 1989. Surgery 1993; 114(6):1050-7; discussion 1057-8.

66) Shah MD, Hall FT, Eski SJ, Witterick IJ, Walfish PG, Freeman JL. Clinical course of thyroid carcinoma after neck dissection. Laryngoscope 2003;113(12):2102-7.

67) Wang TS, Dubner S, Sznyter LA, Heller KS. Incidence of metastatic well-differentiated thyroid cancer in cervical lymph nodes. Arch Otolaryngol Head Neck Surg 2004;130(1):110-3.

68) Sosa JA, Bowman HM, Tielsch JM, Powe NR, Gordon TA, Udelsman R. The importance of surgeon experience for clinical and economic outcomes from thyroidectomy. Ann Surg 1998;228(3):320-30.

69) Friedman M, Pacella BL Jr. Total versus subtotal thyroidectomy. Arguments, approaches, and recommendations. Otolaryngol Clin North Am 1990;23(3):413-27.

70) Brierley JD, Panzarella T, Tsang RW, Gospodarowicz MK, O'Sullivan B. A comparison of different staging systems predictability of patient outcome. Thyroid carcinoma as an example. Cancer 1997;79(12):2414-23.

71) Hay ID, Thompson GB, Grant CS, Bergstralh EJ, Dvorak CE, Gorman CA, et al. Papillary thyroid carcinoma managed at the Mayo Clinic during six decades (1940-1999): temporal trends in initial therapy and long-term outcome in 2444 consecutively treated patients. World J Surg 2002;26(8):879-85.

72) Lin JD, Chao TC, Huang MJ, Weng HF, Tzen KY. Use of radioactive iodine for thyroid remnant ablation in well-differentiated thyroid carcinoma to replace thyroid reoperation. Am J Clin Oncol 1998;21 (1):77-81.

73) Mazzaferri EL. An overview of the management of papillary and follicular thyroid carcinoma. Thyroid 1999;9(5):421-7.

74) Mazzaferri EL. Long-term outcome of patients with differentiated thyroid carcinoma: effect of therapy. Endocr Pract 2000;6(6):469-76.

75) Cooper DS, Specker B, Ho M, Sperling M, Ladenson PW, Ross DS, et al. Thyrotropin suppression and disease progression in patients with differentiated thyroid cancer: results from the National Thyroid Cancer Treatment Cooperative Registry. Thyroid 1998;8(9):737-44.
76) Kim TH, Yang DS, Jung KY, Kim CY, Choi MS. Value of external irradiation for locally advanced papillary thyroid cancer. Int J Radiat Oncol Biol Phys 2003;55(4):1006-12.

77) Grebe SK, Hay ID. Thyroid cancer nodal metastases: biologic significance and therapeutic considerations. Surg Oncol Clin N Am 1996;5(1):43-63

78) Scheumann GF, Gimm O, Wegener G, Hundeshagen H, Dralle H. Prognostic significance and surgical management of locoregional lymph node metastases in papillary thyroid cancer. World J Surg 1994;18(4):559-67; discussion 567-8.

79) Ito Y, Uruno T, Nakano K, Takamura Y, Miya A, Kobayashi K, et al. An observation trial without surgical treatment in patients with papillary microcarcinoma of the thyroid. Thyroid 2003;13(4):381-7.

80) Chow SM, Law SC, Chan JK, Au SK, Yau S, Lau WH. Papillary microcarcinoma of the thyroid-Prognostic significance of lymph node metastasis and multifocality. Cancer 2003;98(1):31-40.

81) Nam-Goong IS, Kim HY, Gong G, Lee HK, Hong SJ, Kim WB, et al. Ultrasonography-guided fine-needle aspiration of thyroid incidentaloma: correlation with pathological findings. Clin Endocrinol (Oxf) 2004;60(1):21-8.

82) Solorzano CC, Carneiro DM, Ramirez M, Lee TM, Irvin GL 3rd. Surgeon-performed ultrasound in the management of thyroid malignancy. Am Surg 2004;70(7):576-80; discussion 580-2.

83) Shimamoto $K$, Satake H, Sawaki A, Ishigaki T, Funahashi H, Imai T. Preoperative staging of thyroid papillary carcinoma with ultrasonography. Eur J Radiol 1998;29(1):4-10.

84) Kresnik E, Gallowitsch HJ, Mikosch P, Stettner H, Igerc I, Gomez I, et al. Fluorine-18-fluorodeoxyglucose positron emission tomography in the preoperative assessment of thyroid nodules in an endemic goiter area. Surgery 2003;133(3):294-9.

85) Zbären P, Becker M, Läng H. Pretherapeutic staging of hypopharyngeal carcinoma. Clinical findings, computed tomography, and magnetic resonance imaging compared with histopathologic evaluation. Arch Otolaryngol Head Neck Surg 1997;123(9):908-13.

86) Goldstein RE, Netterville JL, Burkey B, Johnson JE. Implications of follicular neoplasms, atypia, and lesions suspicious for malignancy diagnosed by fine-needle aspiration of thyroid nodules. Ann Surg 2002;235(5):656-62; discussion 662-4.

87) Schlinkert RT, van Heerden JA, Goellner JR, Gharib H, Smith SL, Rosales RF, et al. Factors that predict malignant thyroid lesions when fine-needle aspiration is "suspicious for follicular neoplasm". Mayo Clin Proc 1997;72(10):913-6.

88) Bilimoria KY, Bentrem DJ, Ko CY, Stewart AK, Winchester DP, Talamonti MS, et al. Extent of surgery affects survival for papillary thyroid cancer. Ann Surg 2007;246(3):375-81; discussion 381-4.

89) Hay ID, Thompson GB, Grant CS, Bergstralh EJ, Dvorak CE, Gorman CA, et al. Papillary thyroid carcinoma managed at the Mayo Clinic during six decades (1940-1999): temporal trends in initial therapy and long-term outcome in 2444 consecutively treated patients. World J Surg 2002;26(8):879-85.

90) Shaha AR, Shah JP, Loree TR. Differentiated thyroid cancer presenting initially with distant metastasis. Am J Surg 1997;174(5):474-6.

91) Sanders LE, Cady B. Differentiated thyroid cancer: reexamination of risk groups and outcome of treatment. Arch Surg 1998;133(4): 419-25.

92) Rouxel A, Hejblum G, Bernier MO, Boëlle PY, Ménégaux F, Mansour $\mathrm{G}$, et al. Prognostic factors associated with the survival of patients developing loco-regional recurrences of differentiated thyroid carcinomas. J Clin Endocrinol Metab 2004;89(11):5362-8.

93) van Heerden JA, Hay ID, Goellner JR, Salomao D, Ebersold JR, Bergstralh EJ, et al. Follicular thyroid carcinoma with capsular invasion alone: a nonthreatening malignancy. Surgery 1992;112(6):11306; discussion 1136-8.

94) Tisell LE, Nilsson B, Mölne J, Hansson G, Fjälling M, Jansson S, et 
al. Improved survival of patients with papillary thyroid cancer after surgical microdissection. World J Surg 1996;20(7):854-9.

95) Kouvaraki MA, Shapiro SE, Fornage BD, Edeiken-Monro BS, Sherman SI, Vassilopoulou-Sellin R, et al. Role of preoperative ultrasonography in the surgical management of patients with thyroid cancer. Surgery 2003;134(6):946-54; discussion 954-5.

96) Olson JA Jr, DeBenedetti MK, Baumann DS, Wells SA Jr. Parathyroid autotransplantation during thyroidectomy. Results of long-term follow-up. Ann Surg 1996;223(5):472-8; discussion 478-80.

97) Gimm O, Rath FW, Dralle H. Pattern of lymph node metastases in papillary thyroid carcinoma. Br J Surg 1998;85(2):252-4.

98) Henry JF, Gramatica L, Denizot A, Kvachenyuk A, Puccini M, Defechereux T. Morbidity of prophylactic lymph node dissection in the central neck area in patients with papillary thyroid carcinoma. Langenbecks Arch Surg 1998;383(2):167-9.

99) Cheah WK, Arici C, Ituarte PH, Siperstein AE, Duh QY, Clark OH. Complications of neck dissection for thyroid cancer. World J Surg 2002;26(8):1013-6.

100) Machens A, Hinze R, Thomusch O, Dralle H. Pattern of nodal metastasis for primary and reoperative thyroid cancer. World J Surg 2002; 26(1):22-8.

101) Gemsenjäger E, Perren A, Seifert B, Schüler G, Schweizer I, Heitz PU. Lymph node surgery in papillary thyroid carcinoma. J Am Coll Surg 2003;197(2):182-90.

102) Ito $Y$, Tomoda $C$, Uruno T, Takamura $Y$, Miya A, Kobayashi K, et al. Preoperative ultrasonographic examination for lymph node metastasis: usefulness when designing lymph node dissection for papillary microcarcinoma of the thyroid. World J Surg 2004;28(5): 498-501.

103) Kupferman ME, Patterson DM, Mandel SJ, LiVolsi V, Weber RS. Safety of modified radical neck dissection for differentiated thyroid carcinoma. Laryngoscope 2004;114(3):403-6.

104) Kupferman ME, Patterson M, Mandel SJ, LiVolsi V, Weber RS. Patterns of lateral neck metastasis in papillary thyroid carcinoma. Arch Otolaryngol Head Neck Surg 2004;130(7):857-60.

105) Goropoulos A, Karamoshos K, Christodoulou A, Ntitsias T, Paulou $\mathrm{K}$, Samaras A, et al. Value of the cervical compartments in the surgical treatment of papillary thyroid carcinoma. World J Surg 2004; 28(12):1275-81.

106) Pacini F, Elisei R, Capezzone M, Miccoli P, Molinaro E, Basolo F, et al. Contralateral papillary thyroid cancer is frequent at completion thyroidectomy with no difference in low- and high-risk patients. Thyroid 2001;11(9):877-81.

107) Pasieka JL, Thompson NW, McLeod MK, Burney RE, Macha M. The incidence of bilateral well-differentiated thyroid cancer found at completion thyroidectomy. World J Surg 1992;16(4):711-6; discussion 716-7.

108) Kim ES, Kim TY, Koh JM, Kim YI, Hong SJ, Kim WB, et al. Completion thyroidectomy in patients with thyroid cancer who initially underwent unilateral operation. Clin Endocrinol (Oxf) 2004;61 (1):145-8

109) Erdem E, Gülçelik MA, Kuru B, Alagöl H. Comparison of completion thyroidectomy and primary surgery for differentiated thyroid carcinoma. Eur J Surg Oncol 2003;29(9):747-9.

110) Shaha AR, Jaffe BM. Completion thyroidectomy: a critical appraisal. Surgery 1992;112(6):1148-52; discussion 1152-3.

111) Randolph GW, Daniels GH. Radioactive iodine lobe ablation as an alternative to completion thyroidectomy for follicular carcinoma of the thyroid. Thyroid 2002;12(11):989-96.

112) Loh KC, Greenspan FS, Gee L, Miller TR, Yeo PP. Pathological tumor-node-metastasis (pTNM) staging for papillary and follicular thyroid carcinomas: a retrospective analysis of 700 patients. J Clin Endocrinol Metab 1997;82(11):3553-62.

113) DeGroot LJ, Kaplan EL, McCormick M, Straus FH. Natural histo- ry, treatment, and course of papillary thyroid carcinoma. J Clin Endocrinol Metab 1990;71(2):414-24.

114) Byar DP, Green SB, Dor P, Williams ED, Colon J, van Gilse HA, et al. A prognostic index for thyroid carcinoma. A study of the E. O.R.T.C. Thyroid Cancer Cooperative Group. Eur J Cancer 1979;15 (8):1033-41.

115) Shaha AR, Loree TR, Shah JP. Prognostic factors and risk group analysis in follicular carcinoma of the thyroid. Surgery 1995;118(6):11316; discussion 1136-8.

116) Sherman SI, Brierley JD, Sperling M, Ain KB, Bigos ST, Cooper DS, et al. Prospective multicenter study of thyrois]carcinoma treatment: initial analysis of staging and outcome. National Thyroid Cancer Treatment Cooperative Study Registry Group. Cancer 1998;83(5):1012-21.

117) Cady B, Rossi R. An expanded view of risk-group definition in differentiated thyroid carcinoma. Surgery 1988;104(6):947-53.

118) Schlumberger M, Berg G, Cohen O, Duntas L, Jamar F, Jarzab B, et al. Follow-up of low-risk patients with differentiated thyroid carcinoma: a European perspective. Eur J Endocrinol 2004;150(2):105-12.

119) Toubeau M, Touzery C, Arveux P, Chaplain G, Vaillant G, Berriolo A, et al. Predictive value for disease progression of serum thyroglobulin levels measured in the postoperative period and after (131)I ablation therapy in patients with differentiated thyroid cancer. J Nucl Med 2004;45(6):988-94.

120) Wenig BM, Thompson LD, Adair CF, Shmookler B, Heffess CS. Thyroid papillary carcinoma of columnar cell type: a clinicopathologic study of 16 cases. Cancer 1998;82(4):740-53.

121) Prendiville S, Burman KD, Ringel MD, Shmookler BM, Deeb ZE, Wolfe K, et al. Tall cell variant: an aggressive form of papillary thyroid carcinoma. Otolaryngol Head Neck Surg 2000;122(3):352-7.

122) Akslen LA, LiVolsi VA. Prognostic significance of histologic grading compared with subclassification of papillary thyroid carcinoma. Cancer 2000;88(8):1902-8.

123) Cailleux AF, Baudin E, Travagli JP, Ricard M, Schlumberger M. Is diagnostic iodine-131 scanning useful after total thyroid ablation for differentiated thyroid cancer? J Clin Endocrinol Metab 2000;85(1): 175-8.

124) Bachelot A, Cailleux AF, Klain M, Baudin E, Ricard M, Bellon N, et al. Relationship between tumor burden and serum thyroglobulin level in patients with papillary and follicular thyroid carcinoma. Thyroid 2002;12(8):707-11.

125) Sanders LE, Cady B. Differentiated thyroid cancer: reexamination of risk groups and outcome of treatment. Arch Surg 1998;133(4): 419-25.

126) Sawka AM, Thephamongkhol K, Brouwers M, Thabane L, Browman G, Gerstein HC. Clinical review 170: A systematic review and metaanalysis of the effectiveness of radioactive iodine remnant ablation for well-differentiated thyroid cancer. J Clin Endocrinol Metab 2004;89(8):3668-76.

127) Kim S, Wei JP, Braveman JM, Brams DM. Predicting outcome and directing therapy for papillary thyroid carcinoma. Arch Surg 2004; 139(4):390-4; discussion 393-4.

128) Sugitani I, Fujimoto Y. Symptomatic versus asymptomatic papillary thyroid microcarcinoma: a retrospective analysis of surgical outcome and prognostic factors. Endocr J 1999;46(1):209-16.

129) Hundahl SA, Fleming ID, Fremgen AM, Menck HR. A National Cancer Data Base report on 53,856 cases of thyroid carcinoma treated in the U.S., 1985-1995 [see commetns]. Cancer 1998;83(12):2638-48.

130) Jung TS, Kim TY, Kim KW, Oh YL, Park do J, Cho BY, et al. Clinical features and prognostic factors for survival in patients with poorly differentiated thyroid carcinoma and comparison to the patients with the aggressive variants of papillary thyroid carcinoma. Endocr J 2007;54(2):265-74.

131) Edmonds CJ, Hayes S, Kermode JC, Thompson BD. Measurement 
of serum TSH and thyroid hormones in the management of treatment of thyroid carcinoma with radioiodine. Br J Radiol 1977;50(599): 799-807.

132) Torres MS, Ramirez L, Simkin PH, Braverman LE, Emerson CH. Effect of various doses of recombinant human thyrotropin on the thyroid radioactive iodine uptake and serum levels of thyroid hormones and thyroglobulin in normal subjects. J Clin Endocrinol Metab 2001;86(4):1660-4.

133) Hershman JM, Edwards CL. Serum thyrotropin (TSH) levels after thyroid ablation compared with TSH levels after exogenous bovine TSH: implications for 131-I treatment of thyroid carcinoma. J Clin Endocrinol Metab 1972;34(5):814-8.

134) Hilts SV, Hellman D, Anderson J, Woolfenden J, Van Antwerp J, Patton D. Serial TSH determination after T3 withdrawal or thyroidectomy in the therapy of thyroid carcinoma. J Nucl Med 1979;20(9): 928-32.

135) Martin ND. Endogenous serum TSH levels and metastatic survey scans in thyroid cancer patients using triiodothyronine withdrawal. Clin Nucl Med 1978;3(10):401-3.

136) Goldman JM, Line BR, Aamodt RL, Robbins J. Influence of triiodothyronine withdrawal time on 131I uptake postthyroidectomy for thyroid cancer. J Clin Endocrinol Metab 1980;50(4):734-9.

137) Schneider AB, Line BR, Goldman JM, Robbins J. Sequential serum thyroglobulin determinations, 131I scans, and 131I uptakes after triiodothyronine withdrawal in patients with thyroid cancer. J Clin Endocrinol Metab 1981;53(6):1199-206.

138) Maxon HR, Thomas SR, Hertzberg VS, Kereiakes JG, Chen IW, Sperling MI, et al. Relation between effective radiation dose and outcome of radioiodine therapy for thyroid cancer. N Engl J Med 1983;309(16):937-41.

139) Liel Y. Preparation for radioactive iodine administration in differentiated thyroid cancer patients. Clin Endocrinol (Oxf) 2002;57(4): 523-7.

140) Sánchez R, Espinosa-de-los-Monteros AL, Mendoza V, Brea E, Hernández I, Sosa E, et al. Adequate thyroid-stimulating hormone levels after levothyroxine discontinuation in the follow-up of patients with well-differentiated thyroid carcinoma. Arch Med Res 2002;33 (5):478-81.

141) Grigsby PW, Siegel BA, Bekker S, Clutter WE, Moley JF. Preparation of patients with thyroid cancer for 131I scintigraphy or therapy by 1-3 weeks of thyroxine discontinuation. J Nucl Med 2004;45(4): $567-70$.

142) Serhal DI, Nasrallah MP, Arafah BM. Rapid rise in serum thyrotropin concentrations after thyroidectomy or withdrawal of suppressive thyroxine therapy in preparation for radioactive iodine administration to patients with differentiated thyroid cancer. J Clin Endocrinol Metab 2004;89(7):3285-9.

143) Carril JM, Quirce R, Serrano J, Banzo I, Jiménez-Bonilla JF, Tabuenca $\mathrm{O}$, et al. Total-body scintigraphy with thallium-201 and iodine-131 in the follow-up of differentiated thyroid cancer. J Nucl Med 1997; 38(5):686-92.

144) Muratet JP, Giraud P, Daver A, Minier JF, Gamelin E, Larra F. Predicting the efficacy of first iodine-131 treatment in differentiated thyroid carcinoma. J Nucl Med 1997;38(9):1362-8.

145) Anderson GS, Fish S, Nakhoda K, Zhuang H, Alavi A, Mandel SJ. Comparison of I-123 and I-131 for whole-body imaging after stimulation by recombinant human thyrotropin: a preliminary report. Clin Nucl Med 2003;28(2):93-6.

146) Gerard SK, Cavalieri RR. I-123 diagnostic thyroid tumor whole-body scanning with imaging at 6, 24, and 48 hours. Clin Nucl Med 2002; 27(1):1-8.

147) Rosário PW, Reis JS, Barroso AL, Rezende LL, Padrão EL, Fagundes TA. Efficacy of low and high 131I doses for thyroid remnant ablation in patients with differentiated thyroid carcinoma based on post- operative cervical uptake. Nucl Med Commun 2004;25(11):1077-81.

148) Bal C, Padhy AK, Jana S, Pant GS, Basu AK. Prospective randomized clinical trial to evaluate the optimal dose of $131 \mathrm{I}$ for remnant ablation in patients with differentiated thyroid carcinoma. Cancer 1996;77(12):2574-80.

149) Creutzig H. High or low dose radioiodine ablation of thyroid remnants? Eur J Nucl Med 1987;12(10):500-2.

150) Johansen K, Woodhouse NJ, Odugbesan O. Comparison of 1073 MBq and $3700 \mathrm{MBq}$ iodine-131 in postoperative ablation of residual thyroid tissue in patients with differentiated thyroid cancer. J Nucl Med 1991;32(2):252-4.

151) Robbins RJ, Larson SM, Sinha N, Shaha A, Divgi C, Pentlow KS, et al. A retrospective review of the effectiveness of recombinant human TSH as a preparation for radioiodine thyroid remnant ablation. J Nucl Med 2002;43(11):1482-8.

152) Pacini F, Molinaro E, Castagna MG, Lippi F, Ceccarelli C, Agate L, et al. Ablation of thyroid residues with $30 \mathrm{mCi}$ (131)I: a comparison in thyroid cancer patients prepared with recombinant human TSH or thyroid hormone withdrawal. J Clin Endocrinol Metab 2002;87 (9):4063-8.

153) Pacini F, Ladenson PW, Schlumberger M, Driedger A, Luster M, Kloos RT, et al. Radioiodine ablation of thyroid remnants after preparation with recombinant human thyrotropin in differentiated thyroid carcinoma: results of an international, randomized, controlled study. J Clin Endocrinol Metab 2006;91(3):926-32.

154) Pilli T, Brianzoni E, Capoccetti F, Castagna MG, Fattori S, Poggiu A, et al. A comparison of $1850(50 \mathrm{mCi})$ and $3700 \mathrm{MBq}(100 \mathrm{mCi})$ 131-iodine administered doses for recombinant thyrotropin-stimulated postoperative thyroid remnant ablation in differentiated thyroid cancer. J Clin Endocrinol Metab 2007;92(9):3542-6.

155) Chianelli M, Todino V, Graziano FM, Panunzi C, Pace D, Guglielmi R, et al. Low-activity (2.0 GBq; $54 \mathrm{mCi}$ ) radioiodine post-surgical remnant ablation in thyroid cancer: comparison between hormone withdrawal and use of rhTSH in low-risk patients. Eur J Endocrinol 2009;160(3):431-6.

156) Tuttle RM, Brokhin M, Omry G, Martorella AJ, Larson SM, Grewal RK, et al. Recombinant human TSH-assisted radioactive iodine remnant ablation achieves short-term clinical recurrence rates similar to those of t3raditional thyroid hormone withdrawal. J Nucl Med 2008;49(5):764-70.

157) Maxon HR, Thomas SR, Boehringer A, Drilling J, Sperling MI, Sparks JC, et al. Low iodine diet in I-131 ablation of thyroid remnants. Clin Nucl Med 1983;8(3):123-6.

158) Goslings BM. Proceedings: Effect of a low iodine diet on 131-I therapy in follicular thyroid carcinomata. J Endocrinol 1975;64(3): 30P.

159) Pluijmen MJ, Eustatia-Rutten C, Goslings BM, Stokkel MP, Arias AM, Diamant M, et al. Effects of low-iodide diet on postsurgical radioiodide ablation therapy in patients with differentiated thyroid carcinoma. Clin Endocrinol (Oxf) 2003;58(4):428-35.

160) Park JT 2nd, Hennessey JV. Two-week low iodine diet is necessary for adequate outpatient preparation for radioiodine rhTSH scanning in patients taking levothyroxine. Thyroid 2004;14(1):57-63.

161) Tomoda C, Uruno T, Takamura Y, Ito Y, Miya A, Kobayashi K, et al. Reevaluation of stringent low iodine diet in outpatient preparation for radioiodine examination and therapy. Endocr J 2005;52(2): 237-40.

162) Morris LF, Wilder MS, Waxman AD, Braunstein GD. Reevaluation of the impact of a stringent low-iodine diet on ablation rates in radioiodine treatment of thyroid carcinoma. Thyroid 2001;11(8):749-55.

163) Fatourechi V, Hay ID, Mullan BP, Wiseman GA, Eghbali-Fatourechi GZ, Thorson LM, et al. Are posttherapy radioiodine scans informative and do they influence subsequent therapy of patients with differentiated thyroid cancer? Thyroid 2000;10(7):573-7. 
164) Sherman SI, Tielens ET, Sostre S, Wharam MD Jr, Ladenson PW. Clinical utility of posttreatment radioiodine scans in the management of patients with thyroid carcinoma. J Clin Endocrinol Metab 1994;78(3):629-34.

165) Souza Rosário PW, Barroso AL, Rezende LL, Padrão EL, Fagundes TA, Penna GC, et al. Post I-131 therapy scanning in patients with thyroid carcinoma metastases: an unnecessary cost or a relevant contribution? Clin Nucl Med 2004;29(12):795-8.

166) McGriff NJ, Csako G, Gourgiotis L, Lori C G, Pucino F, Sarlis NJ. Effects of thyroid hormone suppression therapy on adverse clinical outcomes in thyroid cancer. Ann Med 2002;34(7-8):554-64.

167) Pujol P, Daures JP, Nsakala N, Baldet L, Bringer J, Jaffiol C. Degree of thyrotropin suppression as a prognostic determinant in differentiated thyroid cancer. J Clin Endocrinol Metab 1996;81(12): 4318-23.

168) Toft AD. Clinical practice. Subclinical hyperthyroidism. N Engl J Med 2001;345(7):512-6.

169) Wilson PC, Millar BM, Brierley JD. The management of advanced thyroid cancer. Clin Oncol (R Coll Radiol) 2004;16(8):561-8.

170) Eustatia-Rutten CF, Smit JW, Romijn JA, van der Kleij-Corssmit EP, Pereira AM, Stokkel MP, et al. Diagnostic value of serum thyroglobulin measurements in the follow-up of differentiated thyroid carcinoma, a structured meta-analysis. Clin Endocrinol (Oxf) 2004;61(1):61-74.

171) Bachelot A, Leboulleux S, Baudin E, Hartl DM, Caillou B, Travagli JP, et al. Neck recurrence from thyroid carcinoma: serum thyroglobulin and high-dose total body scan are not reliable criteria for cure after radioiodine treatment. Clin Endocrinol (Oxf) 2005; 62(3):376-9.

172) Brierley JD, Tsang RW. External-beam radiation therapy in the treatment of differentiated thyroid cancer. Semin Surg Oncol 1999; 16(1):42-9.

173) Ronga G, Filesi M, Montesano T, Di Nicola AD, Pace C, Travascio $\mathrm{L}$, et al. Lung metastases from differentiated thyroid carcinoma. A 40 years' experience. Q J Nucl Med Mol Imaging 2004;48(1):12-9.

174) Schlumberger M, Challeton C, De Vathaire F, Travagli JP, Gardet $\mathrm{P}$, Lumbroso JD, et al. Radioactive iodine treatment and external radiotherapy for lung and bone metastases from thyroid carcinoma. J Nucl Med 1996;37(4):598-605.

175) Ilgan S, Karacalioglu AO, Pabuscu Y, Atac GK, Arslan N, Ozturk $\mathrm{E}$, et al. Iodine-131 treatment and high-resolution CT: results in patients with lung metastases from differentiated thyroid carcinoma. Eur J Nucl Med Mol Imaging 2004;31(6):825-30.

176) Bernier MO, Leenhardt L, Hoang C, Aurengo A, Mary JY, Menegaux F, et al. Survival and therapeutic modalities in patients with bone metastases of differentiated thyroid carcinomas. J Clin Endocrinol Metab 2001;86(4):1568-73.

177) Zettinig G, Fueger BJ, Passler C, Kaserer K, Pirich C, Dudczak R, et al. Long-term follow-up of patients with bone metastases from differentiated thyroid carcinoma -- surgery or conventional therapy? Clin Endocrinol (Oxf) 2002;56(3):377-82.

178) Spencer CA, Bergoglio LM, Kazarosyan M, Fatemi S, LoPresti JS. Clinical impact of thyroglobulin $(\mathrm{Tg})$ and $\mathrm{Tg}$ autoantibody method differences on the management of patients with differentiated thyroid carcinomas. J Clin Endocrinol Metab 2005;90(10):5566-75.

179) Spencer CA, LoPresti JS, Fatemi S, Nicoloff JT. Detection of residual and recurrent differentiated thyroid carcinoma by serum thyroglobulin measurement. Thyroid 1999;9(5):435-41.

180) Hollowell JG, Staehling NW, Flanders WD, Hannon WH, Gunter EW, Spencer CA, et al. Serum TSH, T(4), and thyroid antibodies in the United States population (1988 to 1994): National Health and Nutrition Examination Survey (NHANES III). J Clin Endocrinol Metab 2002;87(2):489-99.

181) Spencer CA. Challenges of serum thyroglobulin ( $\mathrm{Tg})$ measure- ment in the presence of Tg autoantibodies. J Clin Endocrinol Metab 2004;89(8):3702-4

182) David A, Blotta A, Rossi R, Zatelli MC, Bondanelli M, Roti E, et al. Clinical value of different responses of serum thyroglobulin to recombinant human thyrotropin in the follow-up of patients with differentiated thyroid carcinoma. Thyroid 2005;15(3):267-73.

183) Baudin E, Do Cao C, Cailleux AF, Leboulleux S, Travagli JP, Schlumberger M. Positive predictive value of serum thyroglobulin levels, measured during the first year of follow-up after thyroid hormone withdrawal, in thyroid cancer patients. J Clin Endocrinol Metab 2003;88(3):1107-11.

184) Schaap J, Eustatia-Rutten CF, Stokkel M, Links TP, Diamant M, van der Velde EA, et al. Does radioiodine therapy have disadvantageous effects in non-iodine accumulating differentiated thyroid carcinoma? Clin Endocrinol (Oxf) 2002;57(1):117-24.

185) Pacini F, Capezzone M, Elisei R, Ceccarelli C, Taddei D, Pinchera A. Diagnostic 131-iodine whole-body scan may be avoided in thyroid cancer patients who have undetectable stimulated serum $\mathrm{Tg}$ levels after initial treatment. J Clin Endocrinol Metab 2002;87(4): 1499-501.

186) Mazzaferri EL, Kloos RT. Clinical review 128: Current approaches to primary therapy for papillary and follicular thyroid cancer. J Clin Endocrinol Metab 2001;86(4):1447-63.

187) Koh JM, Kim ES, Ryu JS, Hong SJ, Kim WB, Shong YK. Effects of therapeutic doses of $131 \mathrm{I}$ in thyroid papillary carcinoma patients with elevated thyroglobulin level and negative 131I whole-body scan: comparative study. Clin Endocrinol (Oxf) 2003;58(4):421-7.

188) Schlumberger M, Mancusi F, Baudin E, Pacini F. 131I therapy for elevated thyroglobulin levels. Thyroid 1997;7(2):273-6.

189) Pacini F, Molinaro E, Castagna MG, Agate L, Elisei R, Ceccarelli $\mathrm{C}$, et al. Recombinant human thyrotropin-stimulated serum thyroglobulin combined with neck ultrasonography has the highest sensitivity in monitoring differentiated thyroid carcinoma. J Clin Endocrinol Metab 2003;88(8):3668-73.

190) Snozek CL, Chambers EP, Reading CC, Sebo TJ, Sistrunk JW, Singh RJ, et al. Serum thyroglobulin, high-resolution ultrasound, and lymph node thyroglobulin in diagnosis of differentiated thyroid carcinoma nodal metastases. J Clin Endocrinol Metab 2007; 92(11):4278-81.

191) Larson SM, Robbins R. Positron emission tomography in thyroid cancer management. Semin Roentgenol 2002;37(2):169-74.

192) Leboulleux S, Schroeder PR, Busaidy NL, Auperin A, Corone C, Jacene HA, et al. Assessment of the incremental value of recombinant thyrotropin stimulation before 2-[18F]-Fluoro-2-deoxy-D-glucose positron emission tomography/computed tomography imaging to localize residual differentiated thyroid cancer. J Clin Endocrinol Metab 2009;94(4):1310-6.

193) Wang PW, Wang ST, Liu RT, Chien WY, Tung SC, Lu YC, Chen HY, Lee $\mathrm{CH}$. Levothyroxine suppression of thyroglobulin in patients with differentiated thyroid carcinoma. J Clin Endocrinol Metab 1999;84(12):4549-53.

194) Dupuy DE, Monchik JM, Decrea C, Pisharodi L. Radiofrequency ablation of regional recurrence from well-differentiated thyroid malignancy. Surgery 2001;130(6):971-7.

195) Lewis BD, Hay ID, Charboneau JW, McIver B, Reading CC, Goellner JR. Percutaneous ethanol injection for treatment of cervical lymph node metastases in patients with papillary thyroid carcinoma. AJR Am J Roentgenol 2002;178(3):699-704.

196) Eustatia-Rutten CF, Romijn JA, Guijt MJ, Vielvoye GJ, van den Berg $\mathrm{R}$, Corssmit EP, et al. Outcome of palliative embolization of bone metastases in differentiated thyroid carcinoma. J Clin Endocrinol Metab 2003;88(7):3184-9.

197) Kloos RT, Mazzaferri EL. A single recombinant human thyrotropin-stimulated serum thyroglobulin measurement predicts differ- 
entiated thyroid carcinoma metastases three to five years later. J Clin Endocrinol Metab 2005;90(9):5047-57.

198) Noguchi S, Yamashita H, Murakami N, Nakayama I, Toda M, Kawamoto H. Small carcinomas of the thyroid. A long-term follow-up of 867 patients. Arch Surg 1996;131(2):187-91.

199) Marchesi M, Biffoni M, Biancari F, Berni A, Campana FP. Predictors of outcome for patients with differentiated and aggressive thyroid carcinoma. Eur J Surg Suppl 2003;(588):46-50.

200) Ge JH, Zhao RL, Hu JL, Zhou WA. [Surgical treatment of advanced thyroid carcinoma with aero-digestive invasion]. Zhonghua Er Bi Yan Hou Ke Za Zhi 2004;39(4):237-40.

201) Avenia N, Ragusa M, Monacelli M, Calzolari F, Daddi N, Di Carlo L, et al. Locally advanced thyroid cancer: therapeutic options. Chir Ital 2004;56(4):501-8.

202) McCaffrey JC. Evaluation and treatment of aerodigestive tract invasion by well-differentiated thyroid carcinoma. Cancer Control 2000;7(3):246-52.

203) Musholt TJ, Musholt PB, Behrend M, Raab R, Scheumann GF, Klempnauer J. Invasive differentiated thyroid carcinoma: tracheal resection and reconstruction procedures in the hands of the endocrine surgeon. Surgery 1999;126(6):1078-87; discussion 1087-8.

204) Czaja JM, McCaffrey TV. The surgical management of laryngotracheal invasion by well-differentiated papillary thyroid carcinoma. Arch Otolaryngol Head Neck Surg 1997;123(5):484-90.

205) Van Nostrand D, Atkins F, Yeganeh F, Acio E, Bursaw R, Wartofsky L. Dosimetrically determined doses of radioiodine for the treatment of metastatic thyroid carcinoma. Thyroid 2002;12(2):121-34.

206) Kulkarni K, Van Nostrand D, Atkins F, Aiken M, Burman K, Wartofsky $\mathrm{L}$. The relative frequency in which empiric dosages of radioiodine would potentially overtreat or undertreat patients who have metastatic well-differentiated thyroid cancer. Thyroid 2006;16(10): 1019-23.

207) Luster M, Lippi F, Jarzab B, Perros P, Lassmann M, Reiners C, et al. rhTSH-aided radioiodine ablation and treatment of differentiated thyroid carcinoma: a comprehensive review. Endocr Relat Cancer 2005;12(1):49-64.

208) Van Tol KM, Hew JM, Jager PL, Vermey A, Dullaart RP, Links TP. Embolization in combination with radioiodine therapy for bone metastases from differentiated thyroid carcinoma. Clin Endocrinol (Oxf) 2000;52(5):653-9.

209) Posteraro AF, Dupuy DE, Mayo-Smith WW. Radiofrequency ablation of bony metastatic disease. Clin Radiol 2004;59(9):803-11.

210) Vitale G, Fonderico F, Martignetti A, Caraglia M, Ciccarelli A, Nuzzo V, et al. Pamidronate improves the quality of life and induces clinical remission of bone metastases in patients with thyroid cancer. Br J Cancer 2001;84(12):1586-90.

211) Masala S, Fiori R, Massari F, Simonetti G. Vertebroplasty and kyphoplasty: new equipment for malignant vertebral fractures treatment. J Exp Clin Cancer Res 2003;22(4 Suppl):75-9.

212) Chiu AC, Delpassand ES, Sherman SI. Prognosis and treatment of brain metastases in thyroid carcinoma. J Clin Endocrinol Metab 1997;82(11):3637-42.

213) Kloos RT, Duvuuri V, Jhiang SM, Cahill KV, Foster JA, Burns JA. Nasolacrimal drainage system obstruction from radioactive iodine therapy for thyroid carcinoma. J Clin Endocrinol Metab 2002;87 (12):5817-20.

214) Mandel SJ, Mandel L. Radioactive iodine and the salivary glands. Thyroid 2003;13(3):265-71.

215) Rubino C, de Vathaire F, Dottorini ME, Hall P, Schvartz C, Couette $\mathrm{JE}$, et al. Second primary malignancies in thyroid cancer patients. Br J Cancer 2003;89(9):1638-44.

216) Chen AY, Levy L, Goepfert H, Brown BW, Spitz MR, Vassilopoulou-Sellin R. The development of breast carcinoma in women with thyroid carcinoma. Cancer 2001;92(2):225-31.
217) Benua RS, Cicale NR, Sonenberg M, Rawson RW. The relation of radioiodine dosimetry to results and complications in the treatment of metastatic thyroid cancer. Am J Roentgenol Radium Ther Nucl Med 1962;87:171-82.

218) Vini L, Hyer S, Al-Saadi A, Pratt B, Harmer C. Prognosis for fertility and ovarian function after treatment with radioiodine for thyroid cancer. Postgrad Med J 2002;78(916):92-3.

219) Dottorini ME, Lomuscio G, Mazzucchelli L, Vignati A, Colombo L. Assessment of female fertility and carcinogenesis after iodine-131 therapy for differentiated thyroid carcinoma. J Nucl Med 1995;36 (1):21-7.

220) Schlumberger M, De Vathaire F, Ceccarelli C, Delisle MJ, Francese C, Couette JE, et al. Exposure to radioactive iodine-131 for scintigraphy or therapy does not preclude pregnancy in thyroid cancer patients. J Nucl Med 1996;37(4):606-12.

221) Wichers M, Benz E, Palmedo H, Biersack HJ, Grünwald F, Klingmüller D. Testicular function after radioiodine therapy for thyroid carcinoma. Eur J Nucl Med 2000;27(5):503-7.

222) Hyer S, Vini L, O’Connell M, Pratt B, Harmer C. Testicular dose and fertility in men following I(131) therapy for thyroid cancer. Clin Endocrinol (Oxf) 2002;56(6):755-8.

223) Sarkar SD, Beierwaltes WH, Gill SP, Cowley BJ. Subsequent fertility and birth histories of children and adolescents treated with 131I for thyroid cancer. J Nucl Med 1976;17(6):460-4.

224) Mazzaferri EL. Gonadal damage from 1311 therapy for thyroid cancer. Clin Endocrinol (Oxf) 2002;57(3):313-4

225) van Tol KM, Jager PL, de Vries EG, Piers DA, Boezen HM, Sluiter WJ, et al. Outcome in patients with differentiated thyroid cancer with negative diagnostic whole-body scanning and detectable stimulated thyroglobulin. Eur J Endocrinol 2003;148(6):589-96.

226) Pineda JD, Lee T, Ain K, Reynolds JC, Robbins J. Iodine-131 therapy for thyroid cancer patients with elevated thyroglobulin and negative diagnostic scan. J Clin Endocrinol Metab 1995;80(5):1488-92.

227) Pacini F, Agate L, Elisei R, Capezzone M, Ceccarelli C, Lippi F, et al. Outcome of differentiated thyroid cancer with detectable serum $\mathrm{Tg}$ and negative diagnostic (131)I whole body scan: comparison of patients treated with high (131)I activities versus untreated patients. J Clin Endocrinol Metab 2001;86(9):4092-7.

228) Wang W, Larson SM, Tuttle RM, Kalaigian H, Kolbert K, Sonenberg $\mathrm{M}$, et al. Resistance of [18f]-fluorodeoxyglucose-avid metastatic thyroid cancer lesions to treatment with high-dose radioactive iodine. Thyroid 2001;11(12):1169-75.

229) Kabasakal L, Selçuk NA, Shafipour H, Ozmen O, Onsel C, Uslu I. Treatment of iodine-negative thyroglobulin-positive thyroid cancer: differences in outcome in patients with macrometastases and patients with micrometastases. Eur J Nucl Med Mol Imaging 2004;31 (11):1500-4.

230) Fatourechi V, Hay ID, Javedan H, Wiseman GA, Mullan BP, Gorman CA. Lack of impact of radioiodine therapy in tg-positive, diagnostic whole-body scan-negative patients with follicular cell-derived thyroid cancer. J Clin Endocrinol Metab 2002;87(4):1521-6.

231) Wang W, Macapinlac H, Larson SM, Yeh SD, Akhurst T, Finn RD, et al. [18F]-2-fluoro-2-deoxy-D-glucose positron emission tomography localizes residual thyroid cancer in patients with negative diagnostic (131)I whole body scans and elevated serum thyroglobulin levels. J Clin Endocrinol Metab 1999;84(7):2291-302.

232) Helal BO, Merlet P, Toubert ME, Franc B, Schvartz C, GauthierKoelesnikov H, et al. Clinical impact of (18)F-FDG PET in thyroid carcinoma patients with elevated thyroglobulin levels and negative (131)I scanning results after therapy. J Nucl Med 2001;42(10): 1464-9.

233) Tsang RW, Brierley JD, Simpson WJ, Panzarella T, Gospodarowicz MK, Sutcliffe SB. The effects of surgery, radioiodine, and external radiation therapy on the clinical outcome of patients with differ- 
entiated thyroid carcinoma. Cancer 1998;82(2):375-88.

234) O'Bryan RM, Baker LH, Gottlieb JE, Rivkin SE, Balcerzak SP, Grumet GN, et al. Dose response evaluation of adriamycin in human neoplasia. Cancer 1977;39(5):1940-8.

235) Gottlieb JA, Hill CS Jr, Ibanez ML, Clark RL. Chemotherapy of thyroid cancer. An evaluation of experience with 37 patients. Cancer 1972;30(3):848-53.

236) Gottlieb JA, Hill CS Jr. Chemotherapy of thyroid cancer with adriamycin. Experience with 30 patients. N Engl J Med 1974;290(4): 193-7.

237) Haugen BR. Management of the patient with progressive radioiodine non-responsive disease. Semin Surg Oncol 1999;16(1):34-41.

238) Ain KB, Egorin MJ, DeSimone PA. Treatment of anaplastic thyroid carcinoma with paclitaxel: phase 2 trial using ninety-six-hour infusion. Collaborative Anaplastic Thyroid Cancer Health Intervention Trials (CATCHIT) Group. Thyroid 2000;10(7):587-94.

239) Santini F, Bottici V, Elisei R, Montanelli L, Mazzeo S, Basolo F, et al. Cytotoxic effects of carboplatinum and epirubicin in the setting of an elevated serum thyrotropin for advanced poorly differentiated thyroid cancer. J Clin Endocrinol Metab 2002;87(9):4160-5.

240) Saad MF, Ordonez NG, Rashid RK, Guido JJ, Hill CS Jr, Hickey RC, et al. Medullary carcinoma of the thyroid. A study of the clinical features and prognostic factors in 161 patients. Medicine (Baltimore) 1984;63(6):319-42.

241) Machens A, Niccoli-Sire P, Hoegel J, Frank-Raue K, van Vroonhoven TJ, Roeher HD, et al. Early malignant progression of hereditary medullary thyroid cancer. N Engl J Med 2003;349(16):1517-25.

242) Horvit PK, Gagel RF. The goitrous patient with an elevated serum calcitonin--what to do? J Clin Endocrinol Metab 1997;82(2):335-7.

243) Pacini F, Fontanelli M, Fugazzola L, Elisei R, Romei C, Di Coscio $\mathrm{G}$, et al. Routine measurement of serum calcitonin in nodular thyroid diseases allows the preoperative diagnosis of unsuspected sporadic medullary thyroid carcinoma. J Clin Endocrinol Metab 1994; 78(4):826-9.

244) Ozgen AG, Hamulu F, Bayraktar F, Yilmaz C, Tüzün M, Yetkin E, et al. Evaluation of routine basal serum calcitonin measurement for early diagnosis of medullary thyroid carcinoma in seven hundred seventy-three patients with nodular goiter. Thyroid 1999;9(6): $579-82$.

245) Rieu M, Lame MC, Richard A, Lissak B, Sambort B, Vuong-Ngoc $\mathrm{P}$, et al. Prevalence of sporadic medullary thyroid carcinoma: the importance of routine measurement of serum calcitonin in the diagnostic evaluation of thyroid nodules. Clin Endocrinol (Oxf) 1995; 42(5):453-60.

246) Cohen R, Campos JM, Salaün C, Heshmati HM, Kraimps JL, Proye $\mathrm{C}$, et al. Preoperative calcitonin levels are predictive of tumor size and postoperative calcitonin normalization in medullary thyroid carcinoma. Groupe d'Etudes des Tumeurs a Calcitonine (GETC). J Clin Endocrinol Metab 2000;85(2):919-22.

247) Greene FL, Sobin LH. The TNM system: our language for cancer care.
J Surg Oncol 2002;80(3):119-20.

248) Brandi ML, Gagel RF, Angeli A, Bilezikian JP, Beck-Peccoz P, Bordi $\mathrm{C}$, et al. Guidelines for diagnosis and therapy of MEN type 1 and type 2. J Clin Endocrinol Metab 2001;86(12):5658-71.

249) Wells SA Jr, Dilley WG, Farndon JA, Leight GS, Baylin SB. Early diagnosis and treatment of medullary thyroid carcinoma. Arch Intern Med 1985;145(7):1248-52.

250) Gilliland FD, Hunt WC, Morris DM, Key CR. Prognostic factors for thyroid carcinoma. A population-based study of 15,698 cases from the Surveillance, Epidemiology and End Results (SEER) program 1973-1991. Cancer 1997;79(3):564-73

251) Moretti F, Farsetti A, Soddu S, Misiti S, Crescenzi M, Filetti S, et al. p53 re-expression inhibits proliferation and restores differentiation of human thyroid anaplastic carcinoma cells. Oncogene 1997; 14(6):729-40

252) Quiros RM, Ding HG, Gattuso P, Prinz RA, Xu X. Evidence that one subset of anaplastic thyroid carcinomas are derived from papillary carcinomas due to BRAF and p53 mutations. Cancer 2005; 103(11):2261-8.

253) Sherman SI. Anaplastic Carcinoma: Clinical Aspects. In Thyroid Cancer: A Comprehensive Guide to Clinical Management. Totowa: Humana Press; 1999.

254) O’Neill JP, O'Neill B, Condron C, Walsh M, Bouchier-Hayes D. Anaplastic (undifferentiated) thyroid cancer: improved insight and therapeutic strategy into a highly aggressive disease. J Laryngol Otol 2005;119(8):585-91.

255) Dahl PR, Brodland DG, Goellner JR, Hay ID. Thyroid carcinoma metastatic to the skin: a cutaneous manifestation of a widely disseminated malignancy. J Am Acad Dermatol 1997;36(4):531-7.

256) Takashima S, Morimoto S, Ikezoe J, Takai S, Kobayashi T, Koyama $\mathrm{H}$, et al. CT evaluation of anaplastic thyroid carcinoma. AJR Am J Roentgenol 1990;154(5):1079-85.

257) Venkatesh YS, Ordonez NG, Schultz PN, Hickey RC, Goepfert H, Samaan NA. Anaplastic carcinoma of the thyroid. A clinicopathologic study of 121 cases. Cancer 1990;66(2):321-30.

258) Sugitani I, Kasai N, Fujimoto Y, Yanagisawa A. Prognostic factors and therapeutic strategy for anaplastic carcinoma of the thyroid. World J Surg 2001;25(5):617-22.

259) Junor EJ, Paul J, Reed NS. Anaplastic thyroid carcinoma: 91 patients treated by surgery and radiotherapy. Eur J Surg Oncol 1992;18(2): 83-8.

260) Kihara M, Miyauchi A, Yamauchi A, Yokomise H. Prognostic factors of anaplastic thyroid carcinoma. Surg Today 2004;34(5):394-8.

261) Heron DE, Karimpour S, Grigsby PW. Anaplastic thyroid carcinoma: comparison of conventional radiotherapy and hyperfractionation chemoradiotherapy in two groups. Am J Clin Oncol 2002;25 (5):442-6.

262) Ain KB. Anaplastic thyroid carcinoma: behavior, biology, and therapeutic approaches. Thyroid 1998;8(8):715-26. 